\title{
Hepatitis C Viral Replication Complex
}

\author{
Hui-Chun Li ${ }^{1}$, Chee-Hing Yang ${ }^{2}$ (D) and Shih-Yen Lo ${ }^{2,3, *(D)}$ \\ 1 Department of Biochemistry, Tzu Chi University, Hualien 97004, Taiwan; huichun@gms.tcu.edu.tw \\ 2 Department of Laboratory Medicine and Biotechnology, Tzu Chi University, Hualien 97004, Taiwan; \\ cheehing2@gms.tcu.edu.tw \\ 3 Department of Laboratory Medicine, Buddhist Tzu Chi General Hospital, Hualien 97004, Taiwan \\ * Correspondence: losylo@mail.tcu.edu.tw; Tel.: +886-3-8565301 (ext. 2322)
}

check for

updates

Citation: Li, H.-C.; Yang, C.-H.; Lo, S.-Y. Hepatitis C Viral Replication Complex. Viruses 2021, 13, 520. https://doi.org/10.3390/v13030520

Academic Editors: Núria Verdaguer and Diego Sebastian Ferrero

Received: 27 February 2021

Accepted: 19 March 2021

Published: 22 March 2021

Publisher's Note: MDPI stays neutral with regard to jurisdictional claims in published maps and institutional affiliations.

Copyright: (C) 2021 by the authors. Licensee MDPI, Basel, Switzerland. This article is an open access article distributed under the terms and conditions of the Creative Commons Attribution (CC BY) license (https:/ / creativecommons.org/licenses/by/ $4.0 /)$.

\begin{abstract}
The life cycle of the hepatitis $\mathrm{C}$ virus (HCV) can be divided into several stages, including viral entry, protein translation, RNA replication, viral assembly, and release. HCV genomic RNA replication occurs in the replication organelles $(\mathrm{RO})$ and is tightly linked to ER membrane alterations containing replication complexes (proteins NS3 to NS5B). The amplification of HCV genomic RNA could be regulated by the $\mathrm{RO}$ biogenesis, the viral RNA structure (i.e., cis-acting replication elements), and both viral and cellular proteins. Studies on HCV replication have led to the development of direct-acting antivirals (DAAs) targeting the replication complex. This review article summarizes the viral and cellular factors involved in regulating HCV genomic RNA replication and the DAAs that inhibit HCV replication.
\end{abstract}

Keywords: hepatitis C virus; replication organelles; NS3 to NS5B proteins; direct-acting antivirals

\section{Introduction}

Infection with the hepatitis $\mathrm{C}$ virus $(\mathrm{HCV})$ can cause chronic hepatitis $\mathrm{C}(\mathrm{CHC})$, liver cirrhosis, hepatocellular carcinoma, and other extra-hepatic manifestations. The prevalence of CHC patients worldwide was around 71 million in 2017 (https: / / www.who. int/hepatitis/publications/global-hepatitis-report2017/en/). HCV belongs to the family Flaviviridae and genus Hepacivirus. Its genome is a single-stranded RNA with positive polarity. Many different but closely related circulating HCV variants (i.e., quasispecies) can be detected in CHC patients due to the low fidelity of the HCV RNA polymerase (NS5B) and its high replication rate [1]. Thus, HCV genomic RNA sequences are highly heterogeneous among different isolates. At present, $\mathrm{HCV}$ is classified into at least six major genotypes (GT 1 to 6) [2,3]. The geographic distribution of different HCV genotypes varies [3]. Subtype 1a is found throughout the US and Northern Europe, while subtype 1b is widely distributed throughout the world and is a major subtype in Japan. Genotype 2 is present in the same areas as genotype 1. Subtype 3a is widely distributed in South Asia and Oceania, while subtype $3 \mathrm{~b}$ is mainly found in East Asia. Genotype 4 is mainly present in the Middle East, Northern to Central Africa, and Europe. Subtype 5a is mainly found in South Africa. Genotype 6 is mainly distributed throughout East and South-East Asia.

The life cycle of HCV begins with its binding to cells. Numerous cellular factors, including proteins, lipids, and glycans, promote the entry of HCV particles into hepatocytes. $\mathrm{HCV}$ initially attaches to the surface proteoglycans, e.g., the scavenger receptor BI, and to the tetraspanin CD81. After lateral translocation to tight junctions, claudin-1 and occludin proteins become essential for HCV entry. HCV particles are engulfed by clathrin-mediated endocytosis and then fused with endosomal membranes in low-pH conditions. Viral genomic RNA is then released into the cytoplasm [4]. Then, the HCV genomic RNA is used for both protein translation and viral RNA replication. HCV RNA replication takes place within the replication organelles (RO) in the endoplasmic reticulum (ER). Finally, $\mathrm{HCV}$ utilizes the biosynthetic pathway of very-low-density lipoprotein to assemble the viral particles and egress from the cells [5]. 
The HCV RNA genome ( 9600 nucleotides) possesses one open reading frame that is flanked by $5^{\prime}$ and $3^{\prime}$ untranslated regions (UTRs) (Figure 1a). Translation of the viral RNA leads to the synthesis of a polyprotein, which is processed into individual viral proteins via cleavages of both cellular and viral proteases. The structural proteins (i.e., the core and envelope glycoproteins E1 and E2) are the main constituents of HCV particles, whereas the viroporin $\mathrm{p} 7$ and nonstructural protein 2 (NS2) are involved in virion assembly [6]. The remaining nonstructural proteins (i.e., NS3, NS4A, NS4B, NS5A, and NS5B; NS3-NS5B) that have specific roles in viral genome amplification form the replication complex [7-9]. The roles of different viral proteins in HCV replication are summarized in Table 1.

(a)

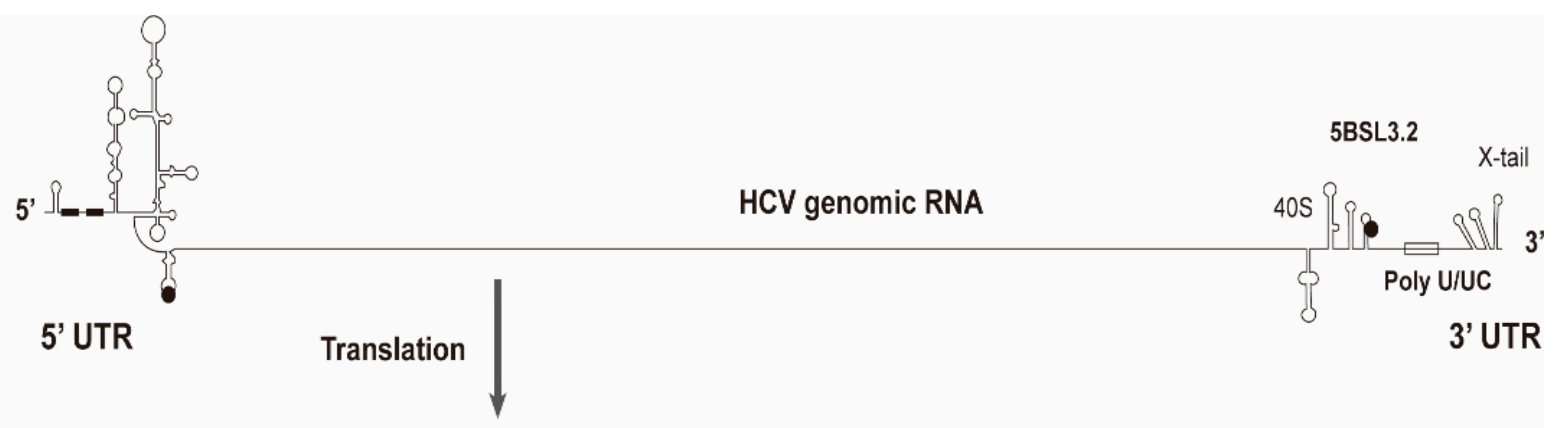

(b)

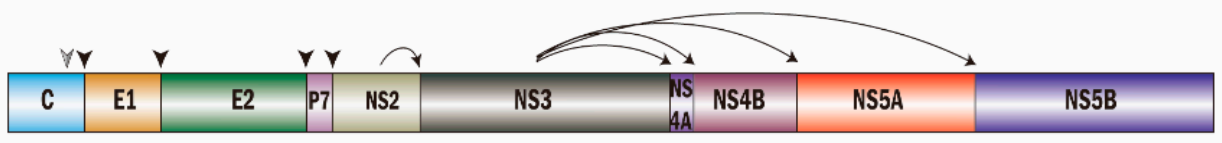

(c)

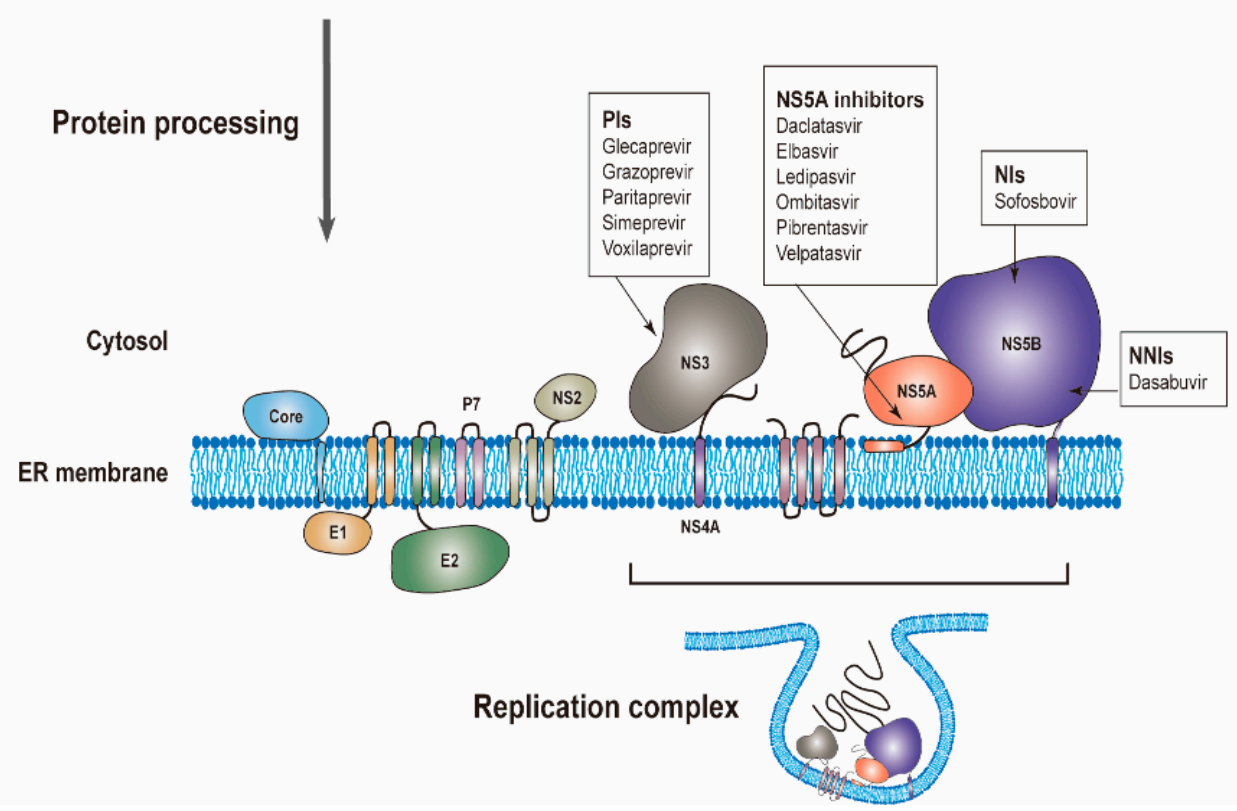

Figure 1. The synthesis of the hepatitis $\mathrm{C}$ virus (HCV) proteins. (a) The start and stop codons for protein translation were marked by black circles, while two recognition sites on the $5^{\prime}$ UTR for miR-122 were marked by black rectangles. (b) The polyprotein is co- and post-translationally cleaved by cellular or viral proteases to yield the structural proteins (core, E1 and E2) and the nonstructural proteins (p7, NS2, NS3, NS4A, NS4B, NS5A and NS5B proteins). The core, E1, and E2 are processed by cellular signal peptidase (filled arrowhead). A mature core protein will be generated after further cleavage by signal peptide peptidase (empty arrowhead). The NS2/NS3 junction site is cleaved by the NS2-NS3 auto-protease, and the remaining nonstructural proteins are processed by the NS3/4A proteinase. (c) All of the HCV proteins are directly or indirectly associated with the endoplasmic reticulum. Currently used anti-HCV direct-acting antivirals (DAAs) target NS3, NS5A, and NS5B, respectively. NS3, NS4A, NS4B, NS5A, and NS5B proteins will form the replication complex. 
Table 1. Hepatitis $\mathrm{C}$ virus (HCV) proteins play different roles in viral replication.

\begin{tabular}{|c|c|}
\hline Viral Protein & Role in HCV Replication \\
\hline Core & $\begin{array}{c}\text { Package HCV genomic RNA to form nucleocapsids and also } \\
\text { involve in lipid synthesis }\end{array}$ \\
\hline E1, E2 & Responsible for the entry of virions to cells \\
\hline p7 & Ion channel \\
\hline NS2 & Auto-protease to cleave the junction between NS2 and NS3 \\
\hline NS3 & $\begin{array}{l}\text { NS3 contains an amino-terminal protease domain responsible for } \\
\text { the HCV polyprotein processing and a carboxy-terminal } \\
\text { DExD-box helicase domain responsible for HCV RNA replication } \\
\text { through unwinding RNA secondary structures }\end{array}$ \\
\hline NS4A & Cofactor for NS3 protease \\
\hline NS4B & $\begin{array}{l}\text { To serve as a scaffold for the viral replication complex and to } \\
\text { induce the rearrangements of membrane vesicles }\end{array}$ \\
\hline NS5A & $\begin{array}{l}\text { To interact with a large number of cellular proteins that are } \\
\text { important for viral assembly and function of the } \\
\text { replication complex }\end{array}$ \\
\hline NS5B & $\begin{array}{l}\text { HCV RNA-dependent-RNA-polymerase responsible for HCV } \\
\text { RNA amplification }\end{array}$ \\
\hline
\end{tabular}

Over thirty years of research on the mechanisms of HCV replication has led to the successful development of direct-acting antivirals (DAAs) targeting the replication complex [10]. We summarize the viral and cellular factors involved in regulating HCV genomic RNA replication and the DAAs inhibiting HCV replication in this review article.

\section{Viral Replication Organelles (RO)}

$\mathrm{HCV}$ induces cellular membrane alterations referred to as the membrane web (MW) for viral RNA replication [11]. Different types of membrane alterations induced by HCV were observed [12,13]. Among these membrane alterations, double-membrane vesicles (DMVs) induced by HCV infection associated with double-stranded RNA (dsRNA) and nonstructural proteins are believed to be the sites of viral genome replication (i.e., viral replication organelles (RO)) in cultured cells (Figure 2). DMVs comprise the predominant $\mathrm{HCV}$-induced membrane structure that forms in the cytoplasm close to the lipid droplets (LDs) in cultured cells. LDs with HCV core and NS5A proteins surrounded by ER is close to the HCV replication (e.g., DMV) and assembly sites. HCV genomic RNA synthesized in the DMVs is transferred by HCV nonstructural proteins and encapsidated by the core proteins to form the nucleocapsid. The HCV nucleocapsid will then interact with glycoproteins E1/E2 in the assembly sites and bud into the ER lumen [14]. DMVs are heterogeneous in size, with an average diameter of $\sim 200 \mathrm{~nm}$. At late time points after infection, multi-membrane vesicles were observed and believed to reflect a stress response induced by high-level virus replication $[13,15,16]$. These HCV-induced DMVs are morphologically similar to those identified in cells infected with coronaviruses, picornaviruses and noroviruses [17]. Previous studies also showed that HCV could induce membrane alterations in the hepatocytes of HCV-infected patients [18,19].

$\mathrm{HCV}$-induced single-membrane vesicles (SMVs) were also detected sporadically in cultured cells $[13,15,16]$. Unlike observations from the cultured cells, a recent report showed that the MW detected in liver tissues of HCV-infected patients seems essentially to be made of clusters of SMVs [20]. Further studies are needed to clarify this issue.

The majority of HCV DMVs appear to be closed structures, and only a few of them have an opening pore toward the cytosol [13]. It is not yet known whether HCV RNA replication takes place on the interior or exterior membrane surface of the DMVs. If HCV RNA replication occurs on the interior surface of DMVs, then a transport mechanism 
must be present to allow the influx of metabolites (e.g., nucleoside triphosphates) required for replication and the exit of newly synthesized viral RNAs for translation or virion assembly [8]. This hypothesis is supported by the findings that HCV hijacks specific cellular components responsible for nucleocytoplasmic transport and that these cellular factors are probably involved in maintaining a transport system between the cytosol and the interior of viral ROs [21,22].

There are several advantages to forming viral ROs for HCV RNA synthesis [17]. First, the viral replication complex (NS3-NS5B) and cellular factors responsible for HCV RNA replication can be concentrated in ROs. Second, ROs, by excluding cellular RNAs, contribute to the template specificity of the replication complex. Third, the replication intermediates (i.e., dsRNA) can be protected from the detection of cellular innate immune sensors. Fourth, ROs facilitate the separation of different stages in the life cycle of HCV (translation vs. replication, replication vs. assembly) by compartmentalization [22]. Fifth, several reports showed that viral RNA and proteins associated with the viral ROs are protected from cellular proteases and nucleases, indicating that RNA replication occurs in a membranous environment separated from the surrounding cytoplasm $[16,23,24]$.
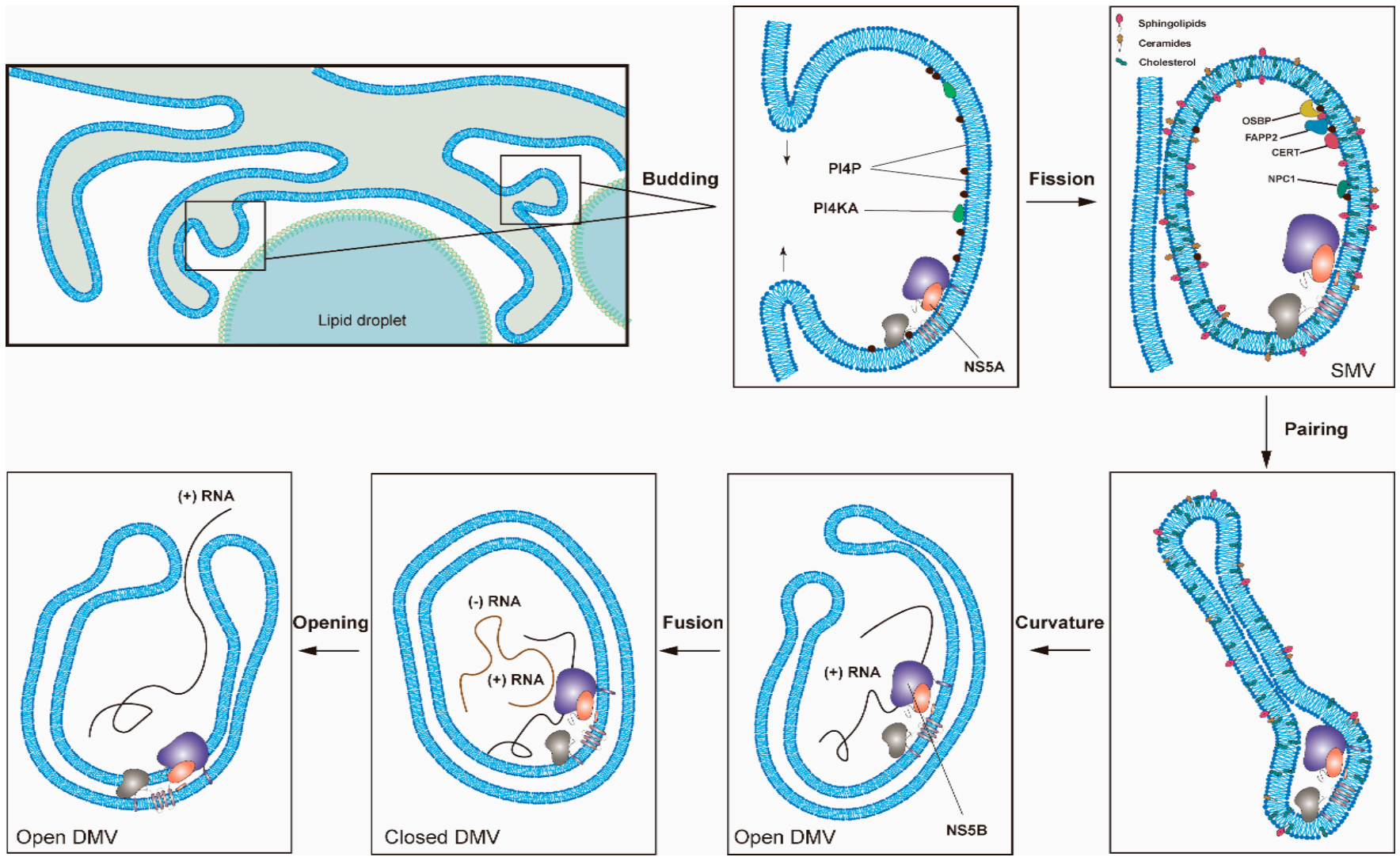

Figure 2. One proposed model for the formation of HCV replication organelles (RO). Double-membrane vesicles (DMV) biogenesis is a complex process possibly requiring several membrane remodeling steps, including budding, fission, pairing, curvature, and fusion [11,17]. HCV DMV formation can be induced by NS5A with the help of other nonstructural proteins $[25,26]$. HCV activates the lipid kinase PI4KIII $\alpha$ to generate enhanced levels of PI4P, which in turn attracts lipid transport proteins (e.g., OSBP, FAPP2, NPC1 and CERT) delivering cholesterol and glycosphingolipids into DMVs. PSTPIP2, a protein with membrane-deforming activity, and PLA2G4C are also critical for membrane web (MW) formation. HCV RNA replication can be conducted by NS5B with the help of other nonstructural proteins in the closed DMVs. After the completion of HCV genomic RNA synthesis, the newly synthesized viral RNAs will be released from the open DMVs (possibly with Kaps or Nups) for translation or virion assembly. Other possible models for DMV formation have also been proposed [11]. 


\subsection{HCV Proteins Involved in RO Formation}

Although any protein of the HCV replication complex (NS3-NS5B) can induce membrane alterations, NS5A is the only one capable of inducing DMV formation $[13,25,26]$. The insertion of the amino-terminal amphipathic $\alpha$-helix of NS5A into just one membrane layer could facilitate the membrane curvature required for $\mathrm{RO}$ formations [27]. The observation that NS5A inhibitors (e.g., daclatasvir) block the HCV RO formation independent of RNA replication demonstrated the essential role of NS5A in the RO formation [28]. The efficiency of the DMV formation induced by NS5A alone is low but is greatly enhanced when the other nonstructural proteins are also expressed, e.g., NS4B, NS3, or NS5B $[26,29,30]$.

Similar to NS5A, NS4B also contains terminal amphipathic $\alpha$-helices, which can alter membrane properties. Moreover, the membrane topology of NS4B is likely to undergo posttranslational changes [31-34], possibly in an NS5A-regulated manner [35]. Moreover, NS4B contains a GXXXXGK P-loop for nucleotide triphosphate binding, which may be involved in membrane rearrangements [36]. In addition, NS4B could form homo-oligomeric complexes, which are required for the RO formation $[29,37,38]$.

\subsection{Cellular Factors Involved in HCV RO Formation}

In addition to having direct involvement in the RO formation, viral proteins also contribute to membrane alterations by recruiting cellular factors required for $\mathrm{RO}$ biogenesis. For example, NS5A. Cyclophilin A (CypA), receptor for activated protein C kinase 1 (RACK1) and ATG14L were found to participate in DMV formation for HCV replication by interacting with NS5A [39-42], while Surf4 and prolactin regulatory element-binding (PREB) participated by interacting with NS4B [43,44]. PSTPIP2 (Proline-serine-threonine phosphatase interacting protein 2) with membrane-deforming activity and PLA2G4C (cytosolic phospholipase A2 gamma) are also important for HCV RO formation via direct interactions with NS4B and NS5A [45,46].

The HCV replication complex is reportedly associated with membrane lipid microdomains (i.e., lipid rafts) [47,48], enriched with cholesterol, sphingolipids, and certain proteins. Lipid rafts generally contain three to five times the cholesterol content found in the surrounding bilayer [49]. Shaping an ER membrane into an RO for HCV RNA replication requires not only viral and cellular proteins but also lipid synthesis [50-52]. Multiple reports have indicated that HCV modulates lipid metabolism (e.g., cholesterol and fatty acid biosynthesis) to promote viral replication [53-55]. This modulation results in de novo lipid biosynthesis in order to increase the membrane surface area required for the RO formation. SREBPs (the sterol regulatory element-binding protein) are major regulators of lipid metabolism and major transcription factors for the expression of genes required for lipid biosynthesis [56]. HCV NS4B has been shown to activate SREBP, leading to the elevated transcription of genes involved in lipogenesis, e.g., fatty acid synthase (FASN) [57].

Modulation of the lipid environment of RO via $\mathrm{HCV}$ also includes the recruitment and activation of the lipid kinase PI4KIII $\alpha$ by NS5A and NS5B proteins to generate enhanced levels of phosphatidylinositol 4-phosphate (PI4P) at the RO [58]. PI4P could attract lipid transport proteins (oxysterol-binding protein (OSBP), four-phosphate adaptor protein 2 (FAPP2), NPC1, and ceramide transfer protein (CERT) to deliver glycosphingolipids, cholesterol, and ceramide to RO, respectively $[16,59,60]$. Recently, it was reported that HCV NS3/4A protease controls the activity of 24-dehydrocholesterol reductase (DHCR24), catalyzing the conversion of desmosterol to cholesterol and regulating the lipid environment for HCV RNA replication [61]. In contrast, cholesterol-25-hydroxylase induced by interferon could block MW formation via the production of 25-hydroxycholesterol and thus restrict HCV replication [62]. Recently, C19orf66, an interferon-stimulated gene, was reported to inhibit HCV by preventing the elevation of PI4P and altering RO formation [63].

In addition to these cellular factors, several studies have shown that autophagy plays an early role in establishing HCV replication [64-66]. DMVs induced by HCV accumulated at the MW are morphologically similar to autophagosomes [15]. Thus, autophagy may 
help to induce MW formation during HCV replication [67]. However, DMVs induced by $\mathrm{HCV}$ with an average diameter of $\sim 200 \mathrm{~nm}$ are smaller than autophagosomes of 500 to $1000 \mathrm{~nm}$ in diameter. The exact role of autophagy in HCV RO formation requires further investigation [68].

Proteins in the nuclear transport machinery (including soluble nuclear transport factors (NTFs), e.g., karyopherins (Kaps)) and nucleoporins (Nups) in the nuclear pore complexes (NPCs) are probably involved in the transfer between the cytosol and the viral ROs [21,22].

\section{Genome Replication}

$\mathrm{HCV}$ genome replication requires at least viral genomic RNA and viral NS5B protein (RNA-dependent RNA polymerase; RdRp) in the ROs. Indeed, NS5B can de novo initiate and copy HCV genomic RNA without the help of other factors in vitro [69-71]. HCV genome replication could be modulated by the HCV RO biogenesis, viral RNA structure (i.e., cis-acting replication elements), viral proteins (particularly, NS5B), and other cellular factors [7].

\subsection{HCV RNA Elements Involved in the Genome Amplification}

Functional RNA structures have been identified throughout the HCV genome [72]. The secondary RNA structural elements found in both the positive-strand viral genome and the negative-strand replication intermediate are important for viral genome amplification. The RNA structures found in the $5^{\prime} \mathrm{UTR}$ of the positive-strand viral genome are primarily involved in translation initiation, but several stem-loop (SL) structures have been associated with genome replication [73]. This association is attributed to the SL elements in the $3^{\prime}$ end of the negative-strand RNA, which forms secondary structures distinct from those found in the positive strand $[74,75]$.

In addition to the $5^{\prime}$ end structural elements of positive-strand RNA, several RNA elements found in the core coding region, the $3^{\prime} \mathrm{UTR}$, and the NS5B-coding region are also essential for genome replication (Figure 1a) [76-79]. The $3^{\prime} \mathrm{UTR}$ is comprised of a variable region, a poly $(\mathrm{U} / \mathrm{UC})$ tract, and a highly conserved $3^{\prime} \mathrm{X}$-tail $[80,81]$. The $\mathrm{X}$-tail contains three SL structures [82]. All of these three SLs are essential for RNA replication [83] and barely tolerate any mutations [84-86]. X-tail is probably the main regulatory element for the initiation of negative-strand synthesis. Initiation of negative-strand RNA synthesis starts at the terminal uridine that is base-paired to guanosine in the $3^{\prime} X$ SL1 [87]. Several long-range RNA-RNA interactions between the $3^{\prime}$ and $5^{\prime}$ elements, facilitated by trans-acting cellular factors, have been shown to potentiate viral genome replication [88-90].

\subsection{HCV Proteins Responsible for Genome Replication}

HCV RNA replication depends on the specific cis- and trans-acting activities of $\mathrm{HCV}$ nonstructural proteins (NS3-NS5B) [91,92]. Recently, NS3-NS5B proteins in RO have been visualized and analyzed using super-resolution microscopy [93].

NS5B (HCV RNA-dependent RNA polymerase) encompasses an amino-terminal catalytic domain that makes up the majority of NS5B, followed by a linker sequence and a C-terminal transmembrane domain (TMD) tethering the catalytic domain to the membrane (Figure 3) $[69,94,95]$. The TMD is essential for RNA replication in cells yet dispensable for enzymatic activity in vitro. Like all other viral RdRps, NS5B has a "right-hand" shape containing palm, thumb, and fingers subdomains [96]. In addition, HCV NS5B contains a $\beta$-flap domain-specific to the RdRps of the Flaviviridae family and a linker domain common to de novo initiating enzymes. Each of these domains contributes to the specific steps in viral RNA synthesis [96]. Regulation at the N-terminal finger subdomain of NS5B through phosphorylation has been demonstrated [97]. 
(a)

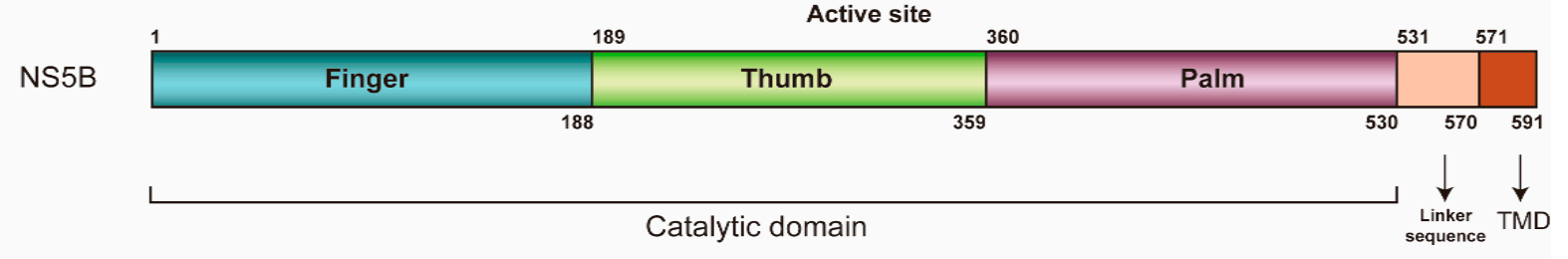

(b)

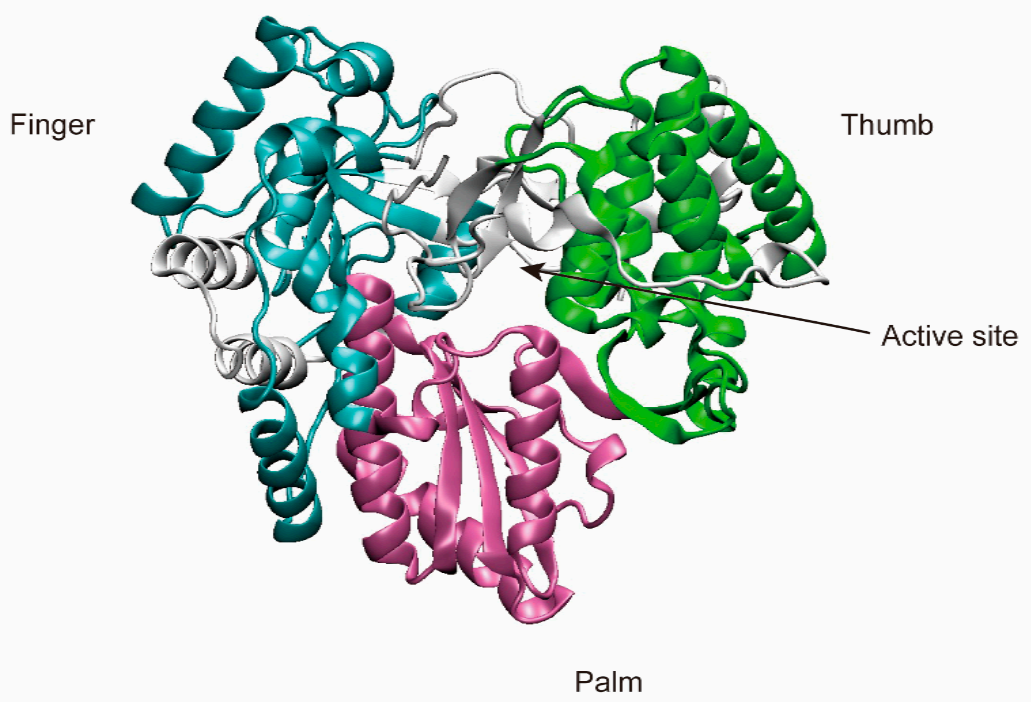

Figure 3. The schematic organization of NS5B's structure. (a) NS5B encompasses an amino-terminal catalytic domain, a linker sequence, and a C-terminal transmembrane domain (TMD). (b) NS5B's catalytic domain has a "right-hand" shape containing palm, thumb, and finger regions (PDB: 3FQK).

The HCV RNA synthetic process conducted by NS5B can be divided into four steps: RNA binding, initiation, elongation, and termination [7]. Structural evidence indicates that NS5B uses de novo initiation to replicate the HCV RNA genome in cells $[69,94,98]$. Moreover, NS5B is capable of internal initiation via functional replication and likely only requires terminal initiation in its natural environment [99]. It is believed that initiation begins at the $3^{\prime}$ end of the HCV genomic RNA and requires high levels of GTP that bind to an allosteric site in the NS5B ( $\beta$-flap domain) to act as structural support to prime the initiation step $[100,101]$. The $3^{\prime}$ end of the positive-strand RNA is a poor template for de novo initiation, as it is concealed within an SL of the X-tail. In contrast, the $3^{\prime}$ end of the negative-strand RNA consists of an SL with an overhang that serves as a highly efficient initiator of RNA synthesis. This difference likely contributes to the 10-fold excess of positive- over negative-strand RNA. HCV NS5B protein alone does not seem to have specificity for the viral genome. However, studies showed that interactions between NS3 helicase, NS5A, and NS5B are required for initiation of RNA synthesis, which indicates that template specificity is conferred by a combination of these viral factors [102].

The closed conformation observed in the crystal structures of NS5B most likely represents the initial state of the enzyme [101,103]. The switch from initiation to elongation seems to be one of the rate-limiting steps, and GTP facilitates this switch [104]. Excess primers are synthesized before NS5B continues to elongate RNA synthesis [104]. A major conformational change towards an open conformation of NS5B is required in this step, probably driven by the removal of the linker sequence to allow the exit of the dsRNA [105]. Residue 405 in the thumb of NS5B seems to be critical for efficient primer synthesis, for switching from initiation to elongation, and for replication efficiency [106,107]. After the initiation of HCV RNA replication, NS5B elongates nascent RNA synthesis by 100 to 400 nucleotides per minute and can copy an entire RNA genome in vitro [70,71,103,108]. NS5B 
protein-protein interactions are also important for the initiation and elongation of RNA de novo synthesis [109]. It is not yet known how HCV RNA synthesis is terminated.

HCV NS5B is believed to be remarkably error-prone and leads to an error rate of $\sim 10^{-4}$ per site in every round of replication, with a strong bias towards G:U/U:G mismatches $[110,111]$. However, NS5B has also been reported to have a nucleotide excision mechanism, which may allow limited error correction [112]. Indeed, a recent report showed that the calculated fidelity of NS5B ranges between $10^{-4}$ and $10^{-9}$ for different mismatches [113].

In addition to NS5B, other viral and cellular proteins also contribute substantially to HCV RNA synthesis. NS5B recruits NS3 to facilitate processive elongation of RNA synthesis [114]. NS3 contains a carboxy-terminal DExD-box helicase domain (NS3h) and an amino-terminal protease domain that functions in conjunction with the cofactor, NS4A (Figure 4). The NS3 protease domain is responsible for HCV polyprotein processing and also contributes to the activity of the helicase domain through an allosteric mechanism [115-117]. Specific mutations in the NS3 helicase domain modulating the nucleic acid unwinding activity, which also affect $\mathrm{HCV}^{\prime}$ s replicative ability, indicate a role of NS3h in HCV RNA synthesis [118-120]. The NS3h may play roles in (i) resolving strong stem-loop structures at the $3^{\prime}$ end of the genome to facilitate initiation of RNA synthesis by NS5B; (ii) unwinding replication intermediates (i.e., dsRNA) during RNA synthesis to support NS5B in the elongation phase; and (iii) striping proteins off the RNA or delivering RNA for packaging into virions via the process of ssRNA translocation $[105,121]$.

(a)

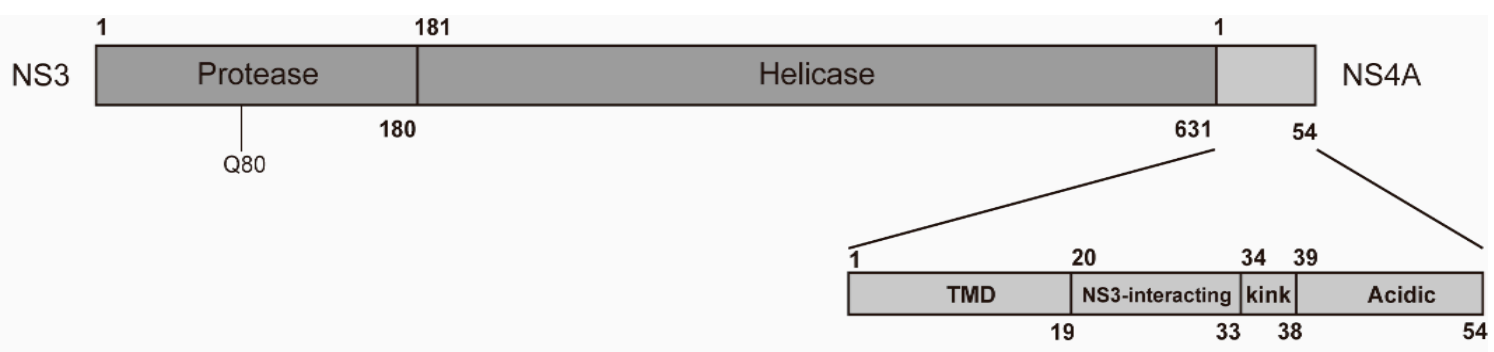

(b)

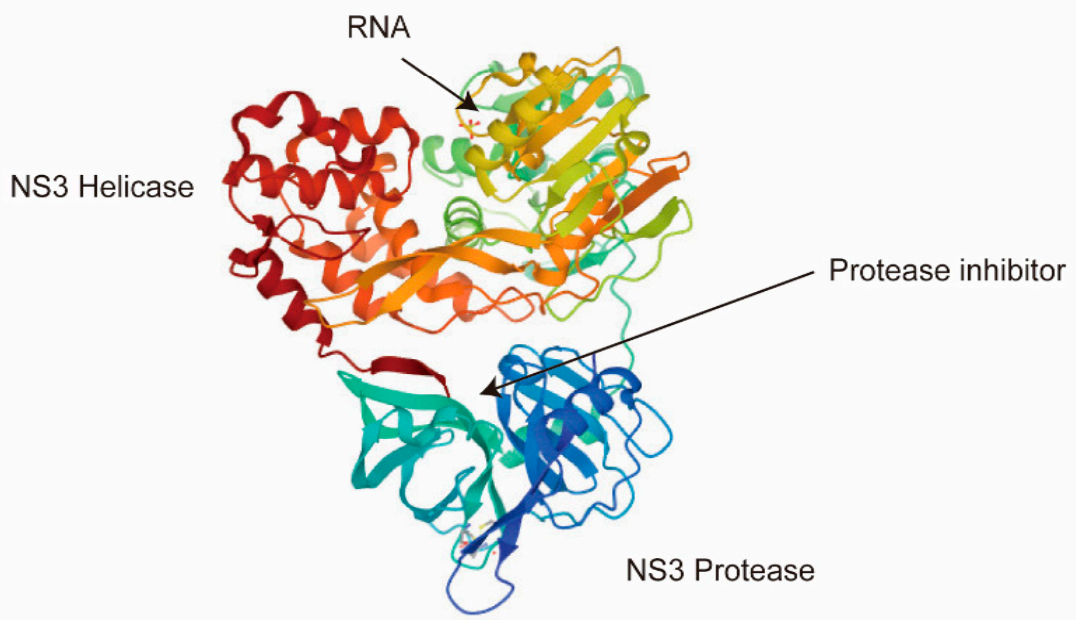

Figure 4. The schematic organization of NS3 and NS4A domains. (a) NS3 contains an amino-terminal protease domain and a carboxy-terminal DExD-box helicase domain. (b) The NS3 protease domain is responsible for HCV polyprotein processing and thus serves as a target for direct-acting antivirals (DAAs). The resistance-associated variants (RAV) of protease inhibitors are often in Q80. The NS3 helicase domain is responsible for HCV RNA replication via the unwinding of RNA secondary structures (PDB: 308B). NS4A contains an N-terminal transmembrane domain (TMD), a central NS3-interacting domain, and a $\mathrm{C}$-terminal domain with a kink region and an acidic region. 
In addition, the linker sequence between the protease and helicase domains of NS3 has been suggested to have a regulatory role in replication and assembly [122].

NS4A is only 54 amino acids (a.a.) long and contains three domains, an N-terminal transmembrane domain, a central NS3-interacting domain, and a C-terminal domain (Figure 4) [123,124]. The N-terminal transmembrane $\alpha$-helix of NS4A anchors NS3 to intracellular membranes. The central domain acts as the NS3 protease cofactor and also interacts with cellular creatine kinase B, which has been reported to augment NS3 helicase activity and HCV replication [125]. The C-terminal domain contains a kink region and an acidic region, which is required for viral assembly and envelopment [126]. The interactions between NS4A and NS4B also control HCV RNA replication [126].

NS4B contains two amino-terminal amphipathic $\alpha$-helices, followed by four transmembrane spanning $\alpha$-helices, and another two carboxy-terminal amphipathic $\alpha$-helices [127]. In addition to supporting $\mathrm{RO}$ formation, NS4B also plays a role in virus replication. The $\mathrm{S} / \mathrm{T}$ cluster and GXXXG motif in the first and second transmembrane segments of NS4B are important for virus replication [128]. NS4B also forms oligomeric complexes via selfinteraction, which is required for HCV RNA replication, in addition to the above-mentioned RO formation $[30,37,38]$. The interaction between the NS4B and NS5A is reportedly involved in viral replication $[129,130]$.

The nonenzymatic NS5A protein is a multifunctional zinc-binding phosphoprotein involved in different stages of the HCV life cycle, including replication, assembly, and egress [131]. NS5A has a length of $\sim 450$ amino acids and contains an N-terminal amphipathic $\alpha$-helix, which is critical for its membrane targeting [132], and three domains (domains I, II and III) separated by two low-complexity sequences (LCS) (Figure 5a). Domain I (a.a. 33-213) is an RNA-binding region linked to virus replication as well as the aforementioned $\mathrm{RO}$ biogenesis and probable functions in several alternative dimerized states $[26,133,134]$. In addition to its role in HCV RNA replication, domain I of NS5A may have a role in virus assembly [135]. Domains II (a.a. 250-342) and III are predicted to be largely unstructured and interact with viral and/or cellular factors, including cyclophilin A and phosphatidylinositol 4-kinase III $\alpha$ (P I4KA) [136,137]. Domain III (a.a. 356-447) functions primarily in virion assembly [138]. NS5A has been reported to help NS5B bind to the HCV RNA template [114].

Different NS5A functions seem to be regulated through differential phosphorylation states [139-144]. Many studies have linked several phosphorylation sites in the LCS region to viral genome replication and show that reducing the phosphorylation of these sites by blocking the casein kinase I isoform $\alpha(\mathrm{CKI} \alpha)$ suppresses $\mathrm{HCV}$ replication and virion assembly [140,145-149]. These results suggest that phosphorylation in the LCS region may function as a regulatory switch between RNA replication and virion assembly. The exact mechanisms for how this multifunctionality is achieved are largely unknown and may be genotype-dependent [150]; however, it is thought that various NS5A phosphor-variants bind to distinct cellular factors, e.g., CypA, P I4KA, VAP A/B, or apolipoprotein E, and then exert different functions [7].

\subsection{Cellular Factors Involved in HCV Genome Replication}

Cellular factors, including lipids, miRNAs, and proteins, are involved in HCV replication $[11,151,152]$. Lipidomic analysis has revealed distinct alterations of cellular lipid composition via HCV infection $[55,153]$. The inhibition of fatty acid synthesis by blocking acetyl-CoA carboxylase decreases viral replication [54]. Furthermore, an increase in saturated and monounsaturated fatty acids augmented HCV replication, while an increase in polyunsaturated fatty acids suppressed replication [54]. Distinct lipids may form lipid rafts required for assembly and viral replication activity. Indeed, the removal of cholesterol from the replication complex impairs its activity [16]. In addition, sphingolipids (e.g., sphingomyelin) were shown to stimulate HCV replication activity [154,155]. A recent report further demonstrated that sphingomyelin is essential for the structure and function of $\mathrm{HCV}$ DMVs [156]. Lipid metabolism is regulated by a family of sterol regulatory element-binding 
proteins (SREBPs), which are transcription factors controlling the expression of more than 30 lipogenic genes. HCV-induced ER stress or viral proteins (e.g., NS4B) could trigger the activation of SREBPs [56,57]. Moreover, the $3^{\prime} \mathrm{UTR}$ of HCV genomic RNA could bind to cellular RNA helicase DDX3X, which acts as an intracellular sensor to induce SREBP expression [157]. Although the effect of HCV infection on cellular lipid metabolism is known, further studies are still needed to clarify how distinct lipids contribute to HCV RNA replication.

(a)

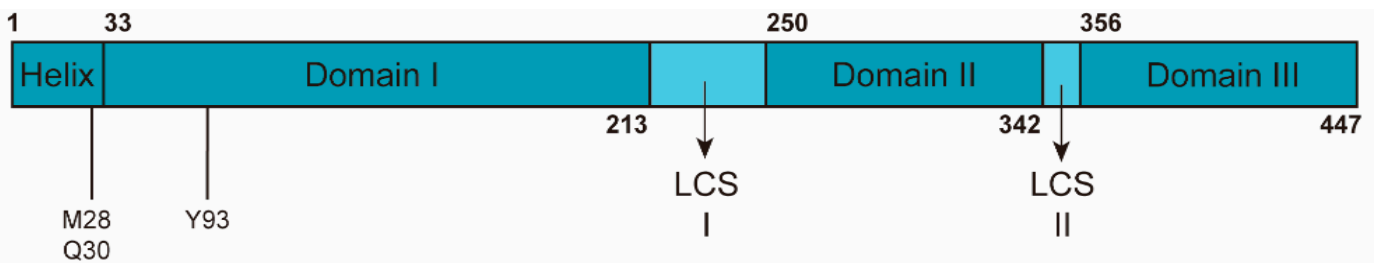

(b)

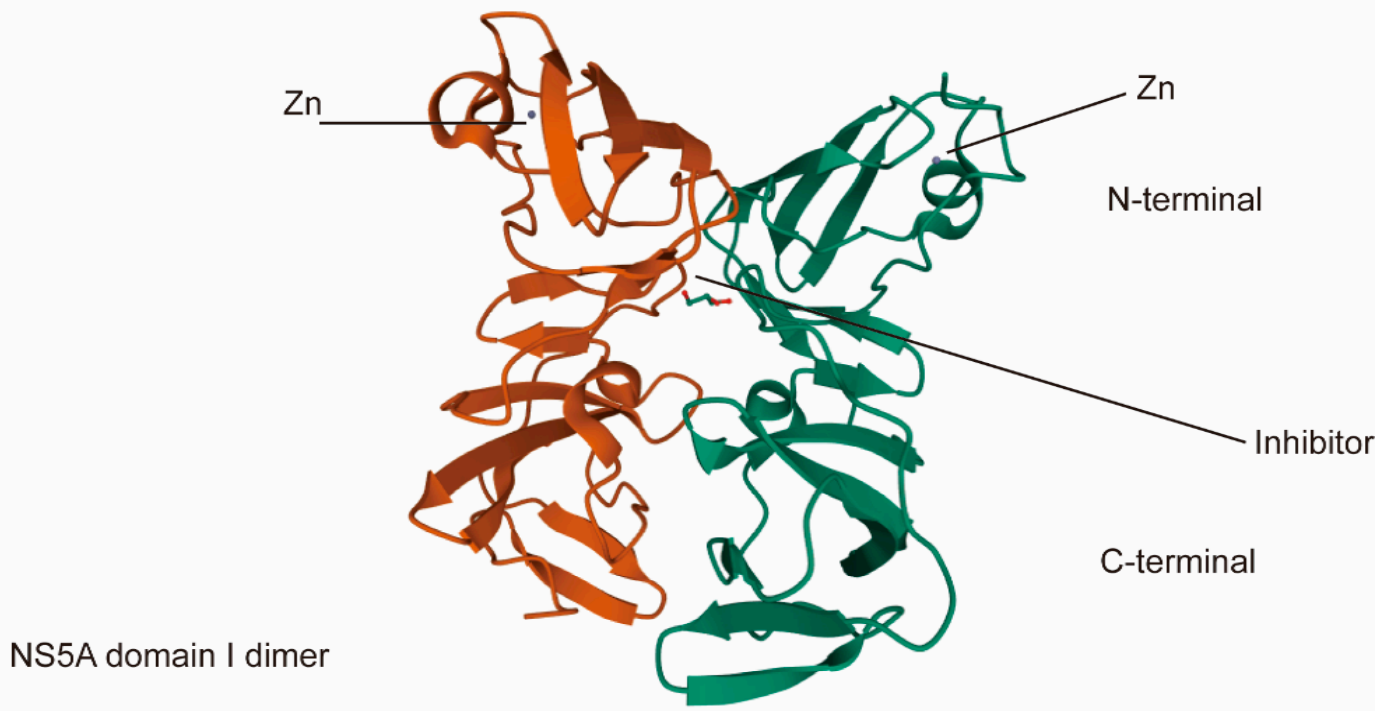

Figure 5. The schematic organization of NS5A domains. (a) NS5A contains an N-terminal amphipathic $\alpha$-helix critical for its targeting of the membrane and three domains (domains I, II and III) separated by two low-complexity sequences (LCS). (b) NS5A inhibitors bind the dimerized domain I, thereby potentially blocking NS5A to exert its functions (PDB: 3FQQ). RAVs of NS5A inhibitors are often in M28, Q30, L31, and Y93.

In addition to lipids, liver-specific miR-122 could bind to the two adjacent sites of HCV 5' UTR (Figure 1a) [158], forming a ternary complex [159]. Through this interaction, in addition to stimulating translation [160], miR122 could also facilitate RNA replication [161] by protecting the genome from cellular DUSP11 pyrophosphatase activity [162] and subsequent degradation by the exonucleases Xrn1 [163,164] and Xrn2 [164,165].

Many cellular proteins are involved in regulating $\mathrm{HCV}$ replication $[7,8,105]$, and only those playing a direct role in HCV RNA replication are mentioned here. Several cellular proteins could facilitate genome circularization and enhance RNA replication by binding to the $5^{\prime}$ - and the $3^{\prime}$-UTR of viral RNA. These proteins include La [166], hnRNP L [167], the NFAR protein complex (NF90, NF45, and RHA) [168], PTB [169], PCBP2 [168] and RNA binding protein 24 [170]. High-mobility group box 1 (HMGB1) interacting with SL 4 of $5^{\prime}$-UTR [171], Src-associated in mitosis 68-kDa (Sam68) protein binding with SL 2 of $5^{\prime}$-UTR [172], and heat shock cognate protein 70 (Hsc 70) interacting with poly-U/UC in the $3^{\prime}$-UTR [173] could also promote HCV replication. 
Several cellular factors enhance HCV RNA replication via interaction with NS5B, including cellular chaperonin TRiC/CCT [174], ribonucleotide reductase M2 (RRM2) [175], HuR [176], VAPB-MSP [177], CYP4F12 [178], and fatty acid synthase [179].

DDX3 [180], Y-box binding protein 1 (YB-1) [180], FKBP6 [181], and human choline kinase- $\alpha(\mathrm{hCK} \alpha)[182,183]$ could interact with NS5A to facilitate HCV RNA replication. Cellular Cyp A [137,184] and human replication protein A (RPA) [114] could bind to NS5A and stimulate the binding of NS5A to NS5B and viral RNA to facilitate HCV RNA replication.

The viral NS3 protein is also an important component of the HCV replication complex. Rad51 [185] and GBF1 [186] could interact with NS3 and promote HCV RNA replication. $\mathrm{Rab}$ (the Ras superfamily of small GTPases) 5 and 7 colocalize with NS4B, and Rab2, 5, and 7 are required for HCV RNA replication [187]. Both VAP-A and VAP-B, enriched in purified DMVs [16], and valosin-containing protein (VCP) [188], interact with NS5A and NS5B and assist in the formation of the replication complex [189,190].

\section{Direct-Acting Antivirals (DAAs)}

A combination of pegylated interferon (IFN) alpha and ribavirin was used to treat HCV-infected patients before 2011 [2,10]. IFN inhibits viral replication by inducing more than 300 interferon-stimulated genes (ISGs) [191]. Indeed, IFN-alpha was reported to inhibit multiple steps of the HCV life cycle, leading to a reduction in viral protein synthesis and eventually suppression of viral RNA amplification [192]. The precise mechanism(s) by which ribavirin exerts its anti-HCV activity is not fully understood. The antiviral activity of ribavirin probably occurs via a combination of different mechanisms [193]: (1) immunomodulation, (2) modulation of ISG expression, (3) inhibition of inosine $5^{\prime}$ monophosphate dehydrogenase by ribavirin $5^{\prime}$-monophosphate, (4) inhibition of eIF4E, (5) inhibition of the HCV RdRp by ribavirin 5'-triphosphate, and (6) induction of viral mutagenesis.

Understanding the $\mathrm{HCV}$ proteins essential for $\mathrm{HCV}$ replication has enabled the development of DAAs targeting viral proteins (NS3 protease activity, NS5A protein and NS5B polymerase) [10,194].

Structural investigations on the NS3/4A protease have facilitated drug developments. The NS3-NS4A protease catalyzes HCV polyprotein cleavage (Figure 1b) [92]. Current NS3/4A inhibitors target the protease activity of NS3/4A. The inhibiting compounds include (I) substrate-derived peptide inhibitors: boceprevir and telaprevir (reversible covalent binders), ciluprevir (P1-P3 macrocycles), BMS605339 (acyl sulfonamide P1) and MK-4519 (P2-P4 macrocycles); (II) second-generation NS3/4a protease inhibitors (faldaprevir, danoprevir, asunaprevir, vaniprevir, simeprevir); (III) novel structural features/classes (sovaprevir and deldeprevir; DX-320; GS-9256 and PHX1766; MK-2748 and vedroprevir; MK-6325; MK-8831); and (IV) third generation NS3/4a protease inhibitors (paritaprevir, grazoprevir, glecaprevir and voxilaprevir) [195].

The current NS5A inhibitors that have been approved for HCV treatment include daclatasvir (DCV), ledipasvir (LDV), ombitasvir (OMV), elbasvir (ELB), velpatasvir (VEL), and pibrentasvir (PIB) [196]. Despite the successful development of DAAs against NS5A, the exact mechanism of these NS5A inhibitors remains largely unknown. Previous studies have shown that NS5A inhibitors bind the dimerized domain I, thereby potentially blocking NS5A to exert its functions (Figure 5b) [28,197]. Indeed, the direct binding of DCV and VEL to the isolated NS5A domain I (a.a. 33-202) and to full-length NS5A has been reported [198,199].

As a key player in HCV RNA synthesis, NS5B is an important target for anti-HCV drug development. Currently, NS5B inhibitors are divided into two categories: nucleoside/nucleotide inhibitors (NIs) and non-nucleoside/nucleotide inhibitors (NNIs) [200]. NIs (e.g., sofosbuvir, SOF) bind to the catalytic pocket of NS5B, while NNIs (e.g., dasabuvir) exhibit noncompetitive mechanisms of action at sites away from the active site. SOF is converted in hepatocytes to an active nucleoside triphosphate form, which competes with uridine triphosphate. Incorporation of the active nucleotide analogs into newly synthesized 
RNA by NS5B was resistant to excision [201] and would block the closure of the NS5B active site upon the binding of the next correct incoming NTP, which prevented further nucleotide addition [202]. NNIs bind to one of five allosteric sites located on either the thumb or palm domains of NS5B, interfere with the conformational changes of NS5B and thus block the polymerase activity [203-206].

\section{Resistance-Associated Variants (RAV)}

Due to the risk of selecting resistance-associated variants (RAV), all-oral interferon-free combined therapies are commonly composed of two or three DAAs inhibiting different targets (NS3 protease, NS5A or NS5B), supplemented with ribavirin if necessary. At present, anti-HCV therapy is considered successful when no virus is detected in the blood 12 weeks after the termination of the treatment (sustained virological response; SVR12) [194,207]. In 2020 , approximately $98 \%$ of CHC patients were successfully cured using the combination of two or three DAAs for a treatment of 8 to 12 weeks [10].

The effectiveness of DAAs as anti-HCV therapies may be affected by resistanceassociated substitutions (RASs) that reduce the viral sensitivity to DAAs and then result in resistance-associated variants (RAVs) [204].

In general, it has been found that RASs present in low proportions $(<15 \%)$ do not significantly affect treatment outcomes [208]. Thus, in this condition, it is not recommended to identify RASs before the treatment (http: / / www.hcvguidelines.org). In contrast, testing for RASs prior to the treatment may help to optimize anti-HCV therapy when RASs comprise a proportion of the overall population greater than 15\% [208].

Several factors may affect the development of RAVs [204]. First among them is the mutation rate of NS5B polymerase. As mentioned earlier, the calculated fidelity of NS5B is between $10^{-4}$ and $10^{-9}$ [113]. The second is the replication rate of the virus. $\mathrm{HCV}$ replication is estimated to be $1.3 \times 10^{12}$ virions per day based on the mathematical model [209]. The third is the genetic barrier. RAVs of drugs with a lower genetic barrier require fewer mutations and thus develop more rapidly. The fourth is fitness. RAVs with low levels of fitness do not replicate well without selection (drug treatment) and thus are not detected by commonly used molecular techniques. Finally, there is the pressure of selection. Exposure to suboptimal concentrations of DAAs will result in the selection of RAVs.

Many RASs associated with treatment failure of DAAs have been identified from NS3 regions, and especially from NS5A. The genetic barrier against the NS3/4A inhibitors is relatively low [210]. Luckily, many NS3 RASs to all generations of NS3/4A inhibitors have a low-level fitness [211], except the Q80K mutation (Figure 4a) [212,213]. After the withdrawal of inhibitors, NS3 RASs disappear gradually as the environmental pressure of selection for these RASs is removed. Thus, NS3 RASs are generally found at low proportions $(0.1 \%$ to $3.1 \%)$ in the patients $[211,214]$.

The genetic barrier to NS5A inhibitors is also low [28]. The clinically significant RASs that have been identified include M28A/G/T, Q30D/E/G/H/K/L/R, L31F/M/V, and $\mathrm{Y} 93 \mathrm{C} / \mathrm{H} / \mathrm{N} / \mathrm{S}$, all of which result in high-level resistance to NS5A inhibitors [215-217]. M28, Q30, and L31 locate in the linker region between the N-terminal $\alpha$-helix and domain I, while Y93 is within domain I on the putative dimer interface of NS5A (Figure 5a) $[28,218,219]$. Due to higher replicative fitness, NS5A RASs persist for years after the removal of inhibitors. Thus, their presence will strongly affect the retreatment outcomes of NS5A inhibitors [204].

The genetic barrier to SOF is very high. Thus, naturally occurring RASs in SOF have rarely been detected in $\mathrm{HCV}$-infected patients. In addition to a high resistance barrier and no detectable pre-existing resistant variants at baseline, SOF also offers pan-genotype coverage. More important, resistance is not an issue for combination therapies with the nucleoside inhibitor. In contrast to SOF, the genetic barrier to NS5B NNIs is relatively low. Thus, the RASs to NS5B NNIs are more commonly detected [220]. As expected, the identity of the RASs that confer resistance to NNIs depends on the particular region targeted by the NNI $[204,211]$. 
The advent of DAAs has led to great success in anti-HCV treatment. However, baseline RASs to DAAs may have a significant effect on treatment outcomes in a certain number of HCV-infected patients. Further understanding of the mechanisms of DAA resistance will help to provide better anti-HCV therapy.

\section{Conclusions}

The study of the life cycle of HCV has progressed significantly following the development of in vitro HCV culture systems [221]. Understanding HCV RNA replication has led to the successful development of DAAs targeting NS3, NS5A, and NS5B. HCV will not integrate its genome into cellular chromosomes and thus allowing the curing of $\mathrm{HCV}$ infection. To achieve the elimination of HCV infection in 2030, as expected by the World Health Organization, screening for asymptomatic carriers and easy access to the DAAs are very important.

Many questions still remain unanswered regarding HCV RNA replication, such as the sequential events driving viral RO biogenesis, the three-dimensional architecture of the viral replication complex, the termination of RNA replication, and the transfer of the newly synthesized viral RNA. Further understanding of HCV RNA replication will not only provide insight into HCV replication strategies but also will shed light on other positivestrand RNA viruses inducing similar reorganizations of cellular membranes, including coronaviruses, picornaviruses, and noroviruses [17,222]. Further investigation of this topic is still needed.

Funding: This research and APC were funded by the Ministry of Science and Technology, R.O.C., grant number MOST 109-2320-B-320-011-MY3 and Tzu Chi University, grant number TCIRP10600104Y3 and TCIRP106001-02Y3.

Institutional Review Board Statement: Not applicable.

Informed Consent Statement: Not applicable.

Conflicts of Interest: The funders had no role in the design of the study, in the collection, analyses, or interpretation of data, in the writing of the manuscript, or in the decision to publish the results.

\section{References}

1. Martell, M.; Esteban, J.I.; Quer, J.; Genesca, J.; Weiner, A.; Esteban, R.; Guardia, J.; Gomez, J. Hepatitis C virus (HCV) circulates as a population of different but closely related genomes: Quasispecies nature of HCV genome distribution. J. Virol. 1992, 66, 3225-3229. [CrossRef] [PubMed]

2. Li, H.C.; Lo, S.Y. Hepatitis C virus: Virology, diagnosis and treatment. World J. Hepatol. 2015, 7, 1377-1389. [CrossRef] [PubMed]

3. Shin-I, T.; Sugiyama, M.; Mizokami, M. Hepatitis C Virus Genotypes and Their Evolution. In Hepatitis C Virus I: Cellular and Molecular Virology; Miyamura, T.L., Lemon, S.M., Walker, C.M., Wakita, T., Eds.; Springer: Tokyo, Japan, 2016 ; pp. $24-29$.

4. Colpitts, C.C.; Tsai, P.L.; Zeisel, M.B. Hepatitis C Virus Entry: An Intriguingly Complex and Highly Regulated Process. Int. J. Mol. Sci. 2020, 21, 2091. [CrossRef] [PubMed]

5. Alazard-Dany, N.; Denolly, S.; Boson, B.; Cosset, F.L. Overview of HCV Life Cycle with a Special Focus on Current and Possible Future Antiviral Targets. Viruses 2019, 11, 30. [CrossRef]

6. Moriishi, K.M.; Matsuura, Y. Structural Proteins of HCV and Biological Functions. In Hepatitis C Virus I: Cellular and Molecular Virology; Miyamura, T.L., Lemon, S.M., Walker, C.M., Wakita, T., Eds.; Springer: Tokyo, Japan, 2016; pp. $105-127$.

7. Tabata, K.; Neufeldt, C.J.; Bartenschlager, R. Hepatitis C Virus Replication. Cold Spring Harb. Perspect. Med. 2020, 10, a037093. [CrossRef]

8. Suzuki, T. Hepatitis C Virus Replication. Adv. Exp. Med. Biol 2017, 997, 199-209.

9. Suzuki, T.; Suzuki, R. Role of Nonstructural Proteins in HCV Replication. In Hepatitis C Virus I: Cellular and Molecular Virology; Miyamura, T.L., Lemon, S.M., Walker, C.M., Wakita, T., Eds.; Springer: Tokyo, Japan, 2016; pp. 129-148.

10. Parlati, L.; Hollande, C.; Pol, S. Treatment of hepatitis C virus infection. Clin. Res. Hepatol. Gastroenterol. 2020, $2020,101578$. [CrossRef]

11. Wang, H.; Tai, A.W. Mechanisms of Cellular Membrane Reorganization to Support Hepatitis C Virus Replication. Viruses 2016, 8, 142. [CrossRef]

12. Ferraris, P.; Beaumont, E.; Uzbekov, R.; Brand, D.; Gaillard, J.; Blanchard, E.; Roingeard, P. Sequential biogenesis of host cell membrane rearrangements induced by hepatitis C virus infection. Cell. Mol. Life Sci. 2013, 70, 1297-1306. [CrossRef] 
13. Romero-Brey, I.; Merz, A.; Chiramel, A.; Lee, J.Y.; Chlanda, P.; Haselman, U.; Santarella-Mellwig, R.; Habermann, A.; Hoppe, S.; Kallis, S.; et al. Three-dimensional architecture and biogenesis of membrane structures associated with hepatitis $C$ virus replication. PLoS Pathog. 2012, 8, e1003056. [CrossRef]

14. Lee, J.Y.; Cortese, M.; Haselmann, U.; Tabata, K.; Romero-Brey, I.; Funaya, C.; Schieber, N.L.; Qiang, Y.; Bartenschlager, M.; Kallis, S.; et al. Spatiotemporal Coupling of the Hepatitis C Virus Replication Cycle by Creating a Lipid Droplet-Proximal Membranous Replication Compartment. Cell Rep. 2019, 27, 3602-3617.e5. [CrossRef] [PubMed]

15. Ferraris, P.; Blanchard, E.; Roingeard, P. Ultrastructural and biochemical analyses of hepatitis C virus-associated host cell membranes. J. Gen. Virol. 2010, 91 Pt 9, 2230-2237. [CrossRef] [PubMed]

16. Paul, D.; Hoppe, S.; Saher, G.; Krijnse-Locker, J.; Bartenschlager, R. Morphological and biochemical characterization of the membranous hepatitis C virus replication compartment. J. Virol. 2013, 87, 10612-10627. [CrossRef] [PubMed]

17. Wolff, G.; Melia, C.E.; Snijder, E.J.; Barcena, M. Double-Membrane Vesicles as Platforms for Viral Replication. Trends Microbiol. 2020, 28, 1022-1033. [CrossRef] [PubMed]

18. Jackson, D.; Tabor, E.; Gerety, R.J. Acute non-A, non-B hepatitis: Specific ultrastructural alterations in endoplasmic reticulum of infected hepatocytes. Lancet 1979, 1, 1249-1250. [CrossRef]

19. Shimizu, Y.K. Ultrastructural alterations and expression of cytoplasmic antigen 48-1 in hepatocytes in association with hepatitis C virus infection. Microbiol. Immunol. 1992, 36, 911-922. [CrossRef] [PubMed]

20. Blanchard, E.; Roingeard, P. The Hepatitis C Virus-Induced Membranous Web in Liver Tissue. Cells 2018, 7, 191. [CrossRef] [PubMed]

21. Neufeldt, C.J.; Joyce, M.A.; Levin, A.; Steenbergen, R.H.; Pang, D.; Shields, J.; Tyrrell, D.L.; Wozniak, R.W. Hepatitis C virusinduced cytoplasmic organelles use the nuclear transport machinery to establish an environment conducive to virus replication. PLoS Pathog. 2013, 9, e1003744. [CrossRef] [PubMed]

22. Neufeldt, C.J.; Joyce, M.A.; Van Buuren, N.; Levin, A.; Kirkegaard, K.; Gale, M., Jr.; Tyrrell, D.L.; Wozniak, R.W. The Hepatitis C Virus-Induced Membranous Web and Associated Nuclear Transport Machinery Limit Access of Pattern Recognition Receptors to Viral Replication Sites. PLoS Pathog. 2016, 12, e1005428. [CrossRef]

23. Miyanari, Y.; Hijikata, M.; Yamaji, M.; Hosaka, M.; Takahashi, H.; Shimotohno, K. Hepatitis C virus non-structural proteins in the probable membranous compartment function in viral genome replication. J. Biol. Chem. 2003, 278, 50301-50308. [CrossRef]

24. Quinkert, D.; Bartenschlager, R.; Lohmann, V. Quantitative analysis of the hepatitis C virus replication complex. J. Virol. 2005, 79, 13594-13605. [CrossRef]

25. Egger, D.; Wolk, B.; Gosert, R.; Bianchi, L.; Blum, H.E.; Moradpour, D.; Bienz, K. Expression of hepatitis C virus proteins induces distinct membrane alterations including a candidate viral replication complex. J. Virol. 2002, 76, 5974-5984. [CrossRef]

26. Romero-Brey, I.; Berger, C.; Kallis, S.; Kolovou, A.; Paul, D.; Lohmann, V.; Bartenschlager, R. NS5A Domain 1 and Polyprotein Cleavage Kinetics Are Critical for Induction of Double-Membrane Vesicles Associated with Hepatitis C Virus Replication. MBio 2015, 6, e00759. [CrossRef] [PubMed]

27. McMahon, H.T.; Boucrot, E. Membrane curvature at a glance. J. Cell Sci. 2015, 128, 1065-1070. [CrossRef]

28. Berger, C.; Romero-Brey, I.; Radujkovic, D.; Terreux, R.; Zayas, M.; Paul, D.; Harak, C.; Hoppe, S.; Gao, M.; Penin, F.; et al. Daclatasvir-like inhibitors of NS5A block early biogenesis of hepatitis C virus-induced membranous replication factories, independent of RNA replication. Gastroenterology 2014, 147, 1094-1105.e25. [CrossRef] [PubMed]

29. Paul, D.; Madan, V.; Ramirez, O.; Bencun, M.; Stoeck, I.K.; Jirasko, V.; Bartenschlager, R. Glycine Zipper Motifs in Hepatitis C Virus Nonstructural Protein 4B Are Required for the Establishment of Viral Replication Organelles. J. Virol. 2018, 92, e01890-17. [CrossRef] [PubMed]

30. Paul, D.; Romero-Brey, I.; Gouttenoire, J.; Stoitsova, S.; Krijnse-Locker, J.; Moradpour, D.; Bartenschlager, R. NS4B self-interaction through conserved C-terminal elements is required for the establishment of functional hepatitis $\mathrm{C}$ virus replication complexes. J. Virol. 2011, 85, 6963-6976. [CrossRef] [PubMed]

31. Palomares-Jerez, F.; Nemesio, H.; Villalain, J. The membrane spanning domains of protein NS4B from hepatitis C virus. Biochim. Biophys. Acta 2012, 1818, 2958-2966. [CrossRef]

32. Palomares-Jerez, M.F.; Nemesio, H.; Franquelim, H.G.; Castanho, M.A.; Villalain, J. N-terminal AH2 segment of protein NS4B from hepatitis C virus. Binding to and interaction with model biomembranes. Biochim. Biophys. Acta 2013, 1828, $1938-1952$. [CrossRef]

33. Palomares-Jerez, M.F; Nemesio, H.; Villalain, J. Interaction with membranes of the full C-terminal domain of protein NS4B from hepatitis C virus. Biochim. Biophys. Acta 2012, 1818, 2536-2549. [CrossRef]

34. Ouldali, M.; Moncoq, K.; de la Valette, A.C.; Arteni, A.A.; Betton, J.M.; Lepault, J. Study of membrane deformations induced by Hepatitis C protein NS4B and its terminal amphipathic peptides. Biochim. Biophys. Acta Biomembr. 2021, 1863, 183537. [CrossRef]

35. Lundin, M.; Lindstrom, H.; Gronwall, C.; Persson, M.A.A. Dual topology of the processed hepatitis C virus protein NS4B is influenced by the NS5A protein. J. Gen. Virol. 2006, 87 Pt 11, 3263-3272. [CrossRef]

36. Einav, S.; Elazar, M.; Danieli, T.; Glenn, J.S. A nucleotide binding motif in hepatitis C virus (HCV) NS4B mediates HCV RNA replication. J. Virol. 2004, 78, 11288-11295. [CrossRef] [PubMed]

37. Gouttenoire, J.; Montserret, R.; Paul, D.; Castillo, R.; Meister, S.; Bartenschlager, R.; Penin, F.; Moradpour, D. Aminoterminal amphipathic alpha-helix AH1 of hepatitis C virus nonstructural protein 4B possesses a dual role in RNA replication and virus production. PLoS Pathog. 2014, 10, e1004501. [CrossRef] [PubMed] 
38. Gouttenoire, J.; Roingeard, P.; Penin, F.; Moradpour, D. Amphipathic alpha-helix AH2 is a major determinant for the oligomerization of hepatitis C virus nonstructural protein 4B. J. Virol. 2010, 84, 12529-12537. [CrossRef] [PubMed]

39. Madan, V.; Paul, D.; Lohmann, V.; Bartenschlager, R. Inhibition of HCV replication by cyclophilin antagonists is linked to replication fitness and occurs by inhibition of membranous web formation. Gastroenterology 2014, 146, 1361-1372.e9. [CrossRef]

40. Lee, J.S.; Tabata, K.; Twu, W.I.; Rahman, M.S.; Kim, H.S.; Yu, J.B.; Jee, M.H.; Bartenschlager, R.; Jang, S.K. RACK1 mediates rewiring of intracellular networks induced by hepatitis $C$ virus infection. PLoS Pathog. 2019, 15, e1008021. [CrossRef]

41. Chatterji, U.; Bobardt, M.; Tai, A.; Wood, M.; Gallay, P.A. Cyclophilin and NS5A inhibitors, but not other anti-hepatitis C virus (HCV) agents, preclude HCV-mediated formation of double-membrane-vesicle viral factories. Antimicrob. Agents Chemother. 2015, 59, 2496-2507. [CrossRef]

42. Chatterji, U.; Bobardt, M.; Schaffer, L.; Wood, M.; Gallay, P.A. Cyclophilin Inhibitors Remodel the Endoplasmic Reticulum of HCV-Infected Cells in a Unique Pattern Rendering Cells Impervious to a Reinfection. PLoS ONE 2016, 11, e0159511. [CrossRef]

43. Kong, L.; Aoyagi, H.; Yang, Z.; Ouyang, T.; Matsuda, M.; Fujimoto, A.; Watashi, K.; Suzuki, R.; Arita, M.; Yamagoe, S.; et al. Surfeit 4 Contributes to the Replication of Hepatitis C Virus Using Double-Membrane Vesicles. J. Virol. 2020, 94, e00858-19. [CrossRef]

44. Kong, L.; Fujimoto, A.; Nakamura, M.; Aoyagi, H.; Matsuda, M.; Watashi, K.; Suzuki, R.; Arita, M.; Yamagoe, S.; Dohmae, N.; et al. Prolactin Regulatory Element Binding Protein Is Involved in Hepatitis C Virus Replication by Interaction with NS4B. J. Virol. 2016, 90, 3093-3111. [CrossRef]

45. Chao, T.C.; Su, W.C.; Huang, J.Y.; Chen, Y.C.; Jeng, K.S.; Wang, H.D.; Lai, M.M. Proline-serine-threonine phosphatase-interacting protein 2 (PSTPIP2), a host membrane-deforming protein, is critical for membranous web formation in hepatitis $C$ virus replication. J. Virol. 2012, 86, 1739-1749. [CrossRef]

46. Xu, S.; Pei, R.; Guo, M.; Han, Q.; Lai, J.; Wang, Y.; Wu, C.; Zhou, Y.; Lu, M.; Chen, X. Cytosolic phospholipase A2 gamma is involved in hepatitis C virus replication and assembly. J. Virol. 2012, 86, 13025-13037. [CrossRef]

47. Aizaki, H.; Lee, K.J.; Sung, V.M.; Ishiko, H.; Lai, M.M. Characterization of the hepatitis C virus RNA replication complex associated with lipid rafts. Virology 2004, 324, 450-461. [CrossRef] [PubMed]

48. Shi, S.T.; Lee, K.J.; Aizaki, H.; Hwang, S.B.; Lai, M.M. Hepatitis C virus RNA replication occurs on a detergent-resistant membrane that cofractionates with caveolin-2. J. Virol. 2003, 77, 4160-4168. [CrossRef] [PubMed]

49. Anchisi, L.; Dessi, S.; Pani, A.; Mandas, A. Cholesterol homeostasis: A key to prevent or slow down neurodegeneration. Front. Physiol. 2012, 3, 486. [CrossRef]

50. Alvisi, G.; Madan, V.; Bartenschlager, R. Hepatitis C virus and host cell lipids: An intimate connection. RNA Biol. 2011, 8, 258-269. [CrossRef] [PubMed]

51. Bley, H.; Schobel, A.; Herker, E. Whole Lotta Lipids-from HCV RNA Replication to the Mature Viral Particle. Int. J. Mol. Sci. 2020, 21, 2888. [CrossRef]

52. Strating, J.R.; van Kuppeveld, F.J. Viral rewiring of cellular lipid metabolism to create membranous replication compartments. Curr. Opin. Cell Biol. 2017, 47, 24-33. [CrossRef]

53. Su, A.I.; Pezacki, J.P.; Wodicka, L.; Brideau, A.D.; Supekova, L.; Thimme, R.; Wieland, S.; Bukh, J.; Purcell, R.H.; Schultz, P.G.; et al. Genomic analysis of the host response to hepatitis C virus infection. Proc. Natl. Acad. Sci. USA 2002, 99, 15669-15674. [CrossRef] [PubMed]

54. Kapadia, S.B.; Chisari, F.V. Hepatitis C virus RNA replication is regulated by host geranylgeranylation and fatty acids. Proc. Natl. Acad. Sci. USA 2005, 102, 2561-2566. [CrossRef] [PubMed]

55. Diamond, D.L.; Syder, A.J.; Jacobs, J.M.; Sorensen, C.M.; Walters, K.A.; Proll, S.C.; McDermott, J.E.; Gritsenko, M.A.; Zhang, Q.; Zhao, R.; et al. Temporal proteome and lipidome profiles reveal hepatitis $\mathrm{C}$ virus-associated reprogramming of hepatocellular metabolism and bioenergetics. PLoS Pathog. 2010, 6, e1000719. [CrossRef] [PubMed]

56. Waris, G.; Felmlee, D.J.; Negro, F.; Siddiqui, A. Hepatitis C virus induces proteolytic cleavage of sterol regulatory element binding proteins and stimulates their phosphorylation via oxidative stress. J. Virol. 2007, 81, 8122-8130. [CrossRef] [PubMed]

57. Park, C.Y.; Jun, H.J.; Wakita, T.; Cheong, J.H.; Hwang, S.B. Hepatitis C virus nonstructural 4B protein modulates sterol regulatory element-binding protein signaling via the AKT pathway. J. Biol. Chem. 2009, 284, 9237-9246. [CrossRef]

58. Reiss, S.; Harak, C.; Romero-Brey, I.; Radujkovic, D.; Klein, R.; Ruggieri, A.; Rebhan, I.; Bartenschlager, R.; Lohmann, V. The lipid kinase phosphatidylinositol-4 kinase III alpha regulates the phosphorylation status of hepatitis C virus NS5A. PLoS Pathog. 2013, 9, e1003359. [CrossRef]

59. Khan, I.; Katikaneni, D.S.; Han, Q.; Sanchez-Felipe, L.; Hanada, K.; Ambrose, R.L.; Mackenzie, J.M.; Konan, K.V. Modulation of hepatitis C virus genome replication by glycosphingolipids and four-phosphate adaptor protein 2. J. Virol. 2014, 88, 12276-12295. [CrossRef]

60. Stoeck, I.K.; Lee, J.Y.; Tabata, K.; Romero-Brey, I.; Paul, D.; Schult, P.; Lohmann, V.; Kaderali, L.; Bartenschlager, R. Hepatitis C Virus Replication Depends on Endosomal Cholesterol Homeostasis. J. Virol 2018, 92, e01196-17. [CrossRef]

61. Tallorin, L.; Villareal, V.A.; Hsia, C.Y.; Rodgers, M.A.; Burri, D.J.; Pfeil, M.P.; Llopis, P.M.; Lindenbach, B.D.; Yang, P.L. Hepatitis $\mathrm{C}$ virus NS3-4A protease regulates the lipid environment for RNA replication by cleaving host enzyme 24-dehydrocholesterol reductase. J. Biol. Chem. 2020, 295, 12426-12436. [CrossRef]

62. Anggakusuma; Romero-Brey, I.; Berger, C.; Colpitts, C.C.; Boldanova, T.; Engelmann, M.; Todt, D.; Perin, P.M.; Behrendt, P.; Vondran, F.W.; et al. Interferon-inducible cholesterol-25-hydroxylase restricts hepatitis $C$ virus replication through blockage of membranous web formation. Hepatology 2015, 62, 702-714. [CrossRef] 
63. Kinast, V.; Plociennikowska, A.; Anggakusuma; Bracht, T.; Todt, D.; Brown, R.J.P.; Boldanova, T.; Zhang, Y.; Bruggemann, Y.; Friesland, M.; et al. C19orf66 is an interferon-induced inhibitor of HCV replication that restricts formation of the viral replication organelle. J. Hepatol. 2020, 73, 549-558. [CrossRef]

64. Dreux, M.; Chisari, F.V. Autophagy proteins promote hepatitis C virus replication. Autophagy 2009, 5, 1224-1225. [CrossRef]

65. Dreux, M.; Gastaminza, P.; Wieland, S.F.; Chisari, F.V. The autophagy machinery is required to initiate hepatitis $C$ virus replication. Proc. Natl. Acad. Sci. USA 2009, 106, 14046-14051. [CrossRef]

66. Guevin, C.; Manna, D.; Belanger, C.; Konan, K.V.; Mak, P.; Labonte, P. Autophagy protein ATG5 interacts transiently with the hepatitis C virus RNA polymerase (NS5B) early during infection. Virology 2010, 405, 1-7. [CrossRef]

67. Mohl, B.P.; Bartlett, C.; Mankouri, J.; Harris, M. Early events in the generation of autophagosomes are required for the formation of membrane structures involved in hepatitis C virus genome replication. J. Gen. Virol. 2016, 97, 680-693. [CrossRef]

68. Chan, S.T.; Ou, J.J. Hepatitis C Virus-Induced Autophagy and Host Innate Immune Response. Viruses 2017, 9, 224. [CrossRef] [PubMed]

69. Lohmann, V.; Korner, F.; Herian, U.; Bartenschlager, R. Biochemical properties of hepatitis C virus NS5B RNA-dependent RNA polymerase and identification of amino acid sequence motifs essential for enzymatic activity. J. Virol. 1997, 71, 8416-8428. [CrossRef] [PubMed]

70. Lohmann, V.; Roos, A.; Korner, F.; Koch, J.O.; Bartenschlager, R. Biochemical and kinetic analyses of NS5B RNA-dependent RNA polymerase of the hepatitis C virus. Virology 1998, 249, 108-118. [CrossRef]

71. Oh, J.W.; Ito, T.; Lai, M.M. A recombinant hepatitis C virus RNA-dependent RNA polymerase capable of copying the full-length viral RNA. J. Virol. 1999, 73, 7694-7702. [CrossRef]

72. Adams, R.L.; Pirakitikulr, N.; Pyle, A.M. Functional RNA structures throughout the Hepatitis C Virus genome. Curr. Opin. Virol. 2017, 24, 79-86. [CrossRef] [PubMed]

73. Friebe, P.; Lohmann, V.; Krieger, N.; Bartenschlager, R. Sequences in the $5^{\prime}$ nontranslated region of hepatitis $C$ virus required for RNA replication. J. Virol. 2001, 75, 12047-12057. [CrossRef] [PubMed]

74. Schuster, C.; Isel, C.; Imbert, I.; Ehresmann, C.; Marquet, R.; Kieny, M.P. Secondary structure of the $3^{\prime}$ terminus of hepatitis C virus minus-strand RNA. J. Virol. 2002, 76, 8058-8068. [CrossRef] [PubMed]

75. Dutkiewicz, M.; Swiatkowska, A.; Figlerowicz, M.; Ciesiolka, J. Structural domains of the $3^{\prime}$-terminal sequence of the hepatitis C virus replicative strand. Biochemistry 2008, 47, 12197-12207. [CrossRef] [PubMed]

76. McMullan, L.K.; Grakoui, A.; Evans, M.J.; Mihalik, K.; Puig, M.; Branch, A.D.; Feinstone, S.M.; Rice, C.M. Evidence for a functional RNA element in the hepatitis C virus core gene. Proc. Natl. Acad. Sci. USA 2007, 104, 2879-2884. [CrossRef]

77. Vassilaki, N.; Friebe, P.; Meuleman, P.; Kallis, S.; Kaul, A.; Paranhos-Baccala, G.; Leroux-Roels, G.; Mavromara, P.; Bartenschlager $\mathrm{R}$. Role of the hepatitis $\mathrm{C}$ virus core +1 open reading frame and core cis-acting RNA elements in viral RNA translation and replication. J. Virol. 2008, 82, 11503-11515. [CrossRef]

78. Pirakitikulr, N.; Kohlway, A.; Lindenbach, B.D.; Pyle, A.M. The Coding Region of the HCV Genome Contains a Network of Regulatory RNA Structures. Mol. Cell 2016, 62, 111-120. [CrossRef]

79. Romero-Lopez, C.; Berzal-Herranz, A. The 5BSL3.2 Functional RNA Domain Connects Distant Regions in the Hepatitis C Virus Genome. Front. Microbiol. 2017, 8, 2093. [CrossRef] [PubMed]

80. Tanaka, T.; Kato, N.; Cho, M.J.; Shimotohno, K. A novel sequence found at the $3^{\prime}$ terminus of hepatitis C virus genome. Biochem. Biophys. Res. Commun. 1995, 215, 744-749. [CrossRef]

81. Kolykhalov, A.A.; Feinstone, S.M.; Rice, C.M. Identification of a highly conserved sequence element at the $3^{\prime}$ terminus of hepatitis C virus genome RNA. J. Virol. 1996, 70, 3363-3371. [CrossRef]

82. Blight, K.J.; Rice, C.M. Secondary structure determination of the conserved 98-base sequence at the $3^{\prime}$ terminus of hepatitis C virus genome RNA. J. Virol. 1997, 71, 7345-7352. [CrossRef]

83. Friebe, P.; Bartenschlager, R. Genetic analysis of sequences in the $3^{\prime}$ nontranslated region of hepatitis $C$ virus that are important for RNA replication. J. Virol. 2002, 76, 5326-5338. [CrossRef]

84. Yi, M.; Lemon, S.M. $3^{\prime}$ nontranslated RNA signals required for replication of hepatitis C virus RNA. J. Virol. 2003, 77, 3557-3568. [CrossRef]

85. Yi, M.; Lemon, S.M. Structure-function analysis of the $3^{\prime}$ stem-loop of hepatitis C virus genomic RNA and its role in viral RNA replication. RNA 2003, 9, 331-345. [CrossRef]

86. Castillo-Martinez, J.; Ovejero, T.; Romero-Lopez, C.; Sanmartin, I.; Berzal-Herranz, B.; Oltra, E.; Berzal-Herranz, A.; Gallego, J. Structure and function analysis of the essential $3^{\prime} X$ domain of hepatitis C virus. RNA 2020, 26, 186-198. [CrossRef]

87. Fricke, M.; Dunnes, N.; Zayas, M.; Bartenschlager, R.; Niepmann, M.; Marz, M. Conserved RNA secondary structures and long-range interactions in hepatitis C viruses. RNA 2015, 21, 1219-1232. [CrossRef]

88. Rance, E.; Tanner, J.E.; Alfieri, C. Genomic-Scale Interaction Involving Complementary Sequences in the Hepatitis C Virus $5^{\prime}$ UTR Domain IIa and the RNA-Dependent RNA Polymerase Coding Region Promotes Efficient Virus Replication. Viruses 2018, 11, 17. [CrossRef]

89. Niepmann, M.; Shalamova, L.A.; Gerresheim, G.K.; Rossbach, O. Signals Involved in Regulation of Hepatitis C Virus RNA Genome Translation and Replication. Front. Microbiol. 2018, 9, 395. [CrossRef] [PubMed]

90. Romero-Lopez, C.; Berzal-Herranz, A. The Role of the RNA-RNA Interactome in the Hepatitis C Virus Life Cycle. Int. J. Mol. Sci. 2020, 21, 1479. [CrossRef] [PubMed] 
91. Kazakov, T.; Yang, F.; Ramanathan, H.N.; Kohlway, A.; Diamond, M.S.; Lindenbach, B.D. Hepatitis C virus RNA replication depends on specific cis- and trans-acting activities of viral nonstructural proteins. PLoS Pathog. 2015, 11, e1004817. [CrossRef] [PubMed]

92. Rice, C.M. New insights into HCV replication: Potential antiviral targets. Top. Antivir. Med. 2011, 19, 117-120. [PubMed]

93. Bartlett, C.; Curd, A.; Peckham, M.; Harris, M. Visualisation and analysis of hepatitis C virus non-structural proteins using super-resolution microscopy. Sci. Rep. 2018, 8, 13604. [CrossRef]

94. Behrens, S.E.; Tomei, L.; De Francesco, R. Identification and properties of the RNA-dependent RNA polymerase of hepatitis C virus. EMBO J. 1996, 15, 12-22. [CrossRef]

95. De Francesco, R.; Behrens, S.E.; Tomei, L.; Altamura, S.; Jiricny, J. RNA-dependent RNA polymerase of hepatitis C virus. Methods Enzymol. 1996, 275, 58-67.

96. Sesmero, E.; Thorpe, I.F. Using the Hepatitis C Virus RNA-Dependent RNA Polymerase as a Model to Understand Viral Polymerase Structure, Function and Dynamics. Viruses 2015, 7, 3974-3994. [CrossRef] [PubMed]

97. Hernandez, S.; Figueroa, D.; Correa, S.; Diaz, A.; Aguayo, D.; Villanueva, R.A. Phosphorylation at the N-terminal finger subdomain of a viral RNA-dependent RNA polymerase. Biochem. Biophys. Res. Commun. 2015, 466, 21-27. [CrossRef] [PubMed]

98. Luo, G.; Hamatake, R.K.; Mathis, D.M.; Racela, J.; Rigat, K.L.; Lemm, J.; Colonno, R.J. De novo initiation of RNA synthesis by the RNA-dependent RNA polymerase (NS5B) of hepatitis C virus. J. Virol. 2000, 74, 851-863. [CrossRef] [PubMed]

99. Schult, P.; Nattermann, M.; Lauber, C.; Seitz, S.; Lohmann, V. Evidence for Internal Initiation of RNA Synthesis by the Hepatitis C Virus RNA-Dependent RNA Polymerase NS5B In Cellulo. J. Virol. 2019, 93, e00525-19. [CrossRef] [PubMed]

100. Lohmann, V.; Overton, H.; Bartenschlager, R. Selective stimulation of hepatitis C virus and pestivirus NS5B RNA polymerase activity by GTP. J. Biol. Chem. 1999, 274, 10807-10815. [CrossRef] [PubMed]

101. Appleby, T.C.; Perry, J.K.; Murakami, E.; Barauskas, O.; Feng, J.; Cho, A.; Fox, D., 3rd; Wetmore, D.R.; McGrath, M.E.; Ray, A.S.; et al. Viral replication. Structural basis for RNA replication by the hepatitis C virus polymerase. Science 2015, 347, 771-775. [CrossRef]

102. Binder, M.; Quinkert, D.; Bochkarova, O.; Klein, R.; Kezmic, N.; Bartenschlager, R.; Lohmann, V. Identification of determinants involved in initiation of hepatitis C virus RNA synthesis by using intergenotypic replicase chimeras. J. Virol. 2007, 81, 5270-5283. [CrossRef]

103. Simister, P.; Schmitt, M.; Geitmann, M.; Wicht, O.; Danielson, U.H.; Klein, R.; Bressanelli, S.; Lohmann, V. Structural and functional analysis of hepatitis C virus strain JFH1 polymerase. J. Virol. 2009, 83, 11926-11939. [CrossRef]

104. Harrus, D.; Ahmed-El-Sayed, N.; Simister, P.C.; Miller, S.; Triconnet, M.; Hagedorn, C.H.; Mahias, K.; Rey, F.A.; Astier-Gin, T.; Bressanelli, S. Further insights into the roles of GTP and the C terminus of the hepatitis $C$ virus polymerase in the initiation of RNA synthesis. J. Biol. Chem. 2010, 285, 32906-32918. [CrossRef] [PubMed]

105. Romero-Brey, I.; Lohmann, V. The HCV Replicase Complex and Viral RNA Synthesis. In Hepatitis C Virus I: Cellular and Molecular Virology; Miyamura, T.L., Lemon, S.M., Walker, C.M., Wakita, T., Eds.; Springer: Tokyo, Japan, 2016.

106. Scrima, N.; Caillet-Saguy, C.; Ventura, M.; Harrus, D.; Astier-Gin, T.; Bressanelli, S. Two crucial early steps in RNA synthesis by the hepatitis C virus polymerase involve a dual role of residue 405. J. Virol. 2012, 86, 7107-7117. [CrossRef] [PubMed]

107. Schmitt, M.; Scrima, N.; Radujkovic, D.; Caillet-Saguy, C.; Simister, P.C.; Friebe, P.; Wicht, O.; Klein, R.; Bartenschlager, R.; Lohmann, V.; et al. A comprehensive structure-function comparison of hepatitis C virus strain JFH1 and J6 polymerases reveals a key residue stimulating replication in cell culture across genotypes. J. Virol. 2011, 85, 2565-2581. [CrossRef]

108. Jin, Z.; Leveque, V.; Ma, H.; Johnson, K.A.; Klumpp, K. Assembly, purification, and pre-steady-state kinetic analysis of active RNA-dependent RNA polymerase elongation complex. J. Biol. Chem. 2012, 287, 10674-10683. [CrossRef]

109. Lopez-Jimenez, A.J.; Clemente-Casares, P.; Sabariegos, R.; Llanos-Valero, M.; Bellon-Echeverria, I.; Encinar, J.A.; Kaushik-Basu, N.; Froeyen, M.; Mas, A. Hepatitis C virus polymerase-polymerase contact interface: Significance for virus replication and antiviral design. Antivir. Res. 2014, 108, 14-24. [CrossRef] [PubMed]

110. Bartenschlager, R.; Lohmann, V. Replication of hepatitis C virus. J. Gen. Virol. 2000, 81 Pt 7, 1631-1648.

111. Powdrill, M.H.; Tchesnokov, E.P.; Kozak, R.A.; Russell, R.S.; Martin, R.; Svarovskaia, E.S.; Mo, H.; Kouyos, R.D.; Gotte, M. Contribution of a mutational bias in hepatitis $C$ virus replication to the genetic barrier in the development of drug resistance. Proc. Natl. Acad. Sci. USA 2011, 108, 20509-20513. [CrossRef]

112. Jin, Z.; Leveque, V.; Ma, H.; Johnson, K.A.; Klumpp, K. NTP-mediated nucleotide excision activity of hepatitis C virus RNAdependent RNA polymerase. Proc. Natl. Acad. Sci. USA 2013, 110, E348-E357. [CrossRef]

113. Villalba, B.; Johnson, K.A. Rate-limiting pyrophosphate release by hepatitis C virus polymerase NS5B improves fidelity. J. Biol. Chem. 2020, 295, 16436-16444. [CrossRef]

114. Mani, N.; Yuzhakov, A.; Yuzhakov, O.; Coll, J.T.; Black, J.; Saxena, K.; Fulghum, J.R.; Lippke, J.A.; Rao, B.G.; Rijnbrand, R.; et al. Nonstructural protein 5A (NS5A) and human replication protein A increase the processivity of hepatitis C virus NS5B polymerase activity in vitro. J. Virol. 2015, 89, 165-180. [CrossRef]

115. Beran, R.K.; Serebrov, V.; Pyle, A.M. The serine protease domain of hepatitis C viral NS3 activates RNA helicase activity by promoting the binding of RNA substrate. J. Biol. Chem. 2007, 282, 34913-34920. [CrossRef]

116. Ding, S.C.; Kohlway, A.S.; Pyle, A.M. Unmasking the active helicase conformation of nonstructural protein 3 from hepatitis C virus. J. Virol. 2011, 85, 4343-4353. [CrossRef] [PubMed] 
117. Saalau-Bethell, S.M.; Woodhead, A.J.; Chessari, G.; Carr, M.G.; Coyle, J.; Graham, B.; Hiscock, S.D.; Murray, C.W.; Pathuri, P.; Rich, S.J.; et al. Discovery of an allosteric mechanism for the regulation of HCV NS3 protein function. Nat. Chem. Biol. 2012, 8, 920-925. [CrossRef] [PubMed]

118. Stross, C.; Shimakami, T.; Haselow, K.; Ahmad, M.Q.; Zeuzem, S.; Lange, C.M.; Welsch, C. Natural HCV variants with increased replicative fitness due to NS3 helicase mutations in the C-terminal helix alpha18. Sci. Rep. 2016, 6, 19526. [CrossRef] [PubMed]

119. Zhou, T.; Ren, X.; Adams, R.L.; Pyle, A.M. NS3 from Hepatitis C Virus Strain JFH-1 Is an Unusually Robust Helicase That Is Primed to Bind and Unwind Viral RNA. J. Virol. 2018, 92, e01253-17. [CrossRef]

120. Gu, M.; Rice, C.M. The Spring alpha-Helix Coordinates Multiple Modes of HCV (Hepatitis C Virus) NS3 Helicase Action. J. Biol. Chem. 2016, 291, 14499-14509. [CrossRef]

121. Gu, M.; Rice, C.M. Three conformational snapshots of the hepatitis C virus NS3 helicase reveal a ratchet translocation mechanism. Proc. Natl. Acad. Sci. USA 2010, 107, 521-528. [CrossRef]

122. Kohlway, A.; Pirakitikulr, N.; Ding, S.C.; Yang, F.; Luo, D.; Lindenbach, B.D.; Pyle, A.M. The linker region of NS3 plays a critical role in the replication and infectivity of hepatitis C virus. J. Virol. 2014, 88, 10970-10974. [CrossRef]

123. Beran, R.K.; Lindenbach, B.D.; Pyle, A.M. The NS4A protein of hepatitis C virus promotes RNA-coupled ATP hydrolysis by the NS3 helicase. J. Virol. 2009, 83, 3268-3275. [CrossRef]

124. Gu, M.; Rice, C.M. Structures of hepatitis C virus nonstructural proteins required for replicase assembly and function. Curr. Opin. Virol. 2013, 3, 129-136. [CrossRef]

125. Hara, H.; Aizaki, H.; Matsuda, M.; Shinkai-Ouchi, F.; Inoue, Y.; Murakami, K.; Shoji, I.; Kawakami, H.; Matsuura, Y.; Lai, M.M.; et al. Involvement of creatine kinase B in hepatitis C virus genome replication through interaction with the viral NS4A protein. J. Virol. 2009, 83, 5137-5147. [CrossRef] [PubMed]

126. Phan, T.; Kohlway, A.; Dimberu, P.; Pyle, A.M.; Lindenbach, B.D. The acidic domain of hepatitis C virus NS4A contributes to RNA replication and virus particle assembly. J. Virol. 2011, 85, 1193-1204. [CrossRef] [PubMed]

127. Bartenschlager, R.; Lohmann, V.; Penin, F. The molecular and structural basis of advanced antiviral therapy for hepatitis $C$ virus infection. Nat. Rev. Microbiol. 2013, 11, 482-496. [CrossRef]

128. Han, Q.; Aligo, J.; Manna, D.; Belton, K.; Chintapalli, S.V.; Hong, Y.; Patterson, R.L.; van Rossum, D.B.; Konan, K.V. Conserved GXXXG- and S/T-like motifs in the transmembrane domains of NS4B protein are required for hepatitis C virus replication. J. Virol. 2011, 85, 6464-6479. [CrossRef]

129. David, N.; Yaffe, Y.; Hagoel, L.; Elazar, M.; Glenn, J.S.; Hirschberg, K.; Sklan, E.H. The interaction between the hepatitis C proteins NS4B and NS5A is involved in viral replication. Virology 2015, 475, 139-149. [CrossRef] [PubMed]

130. Biswas, A.; Treadaway, J.; Tellinghuisen, T.L. Interaction between Nonstructural Proteins NS4B and NS5A Is Essential for Proper NS5A Localization and Hepatitis C Virus RNA Replication. J. Virol. 2016, 90, 7205-7218. [CrossRef] [PubMed]

131. Ross-Thriepland, D.; Harris, M. Hepatitis C virus NS5A: Enigmatic but still promiscuous 10 years on! J. Gen. Virol. 2015, 96 Pt 4 , 727-738. [CrossRef]

132. Penin, F.; Brass, V.; Appel, N.; Ramboarina, S.; Montserret, R.; Ficheux, D.; Blum, H.E.; Bartenschlager, R.; Moradpour, D. Structure and function of the membrane anchor domain of hepatitis $C$ virus nonstructural protein 5A. J. Biol. Chem. 2004, 279, 40835-40843. [CrossRef]

133. Huang, L.; Hwang, J.; Sharma, S.D.; Hargittai, M.R.; Chen, Y.; Arnold, J.J.; Raney, K.D.; Cameron, C.E. Hepatitis C virus nonstructural protein 5A (NS5A) is an RNA-binding protein. J. Biol. Chem. 2005, 280, 36417-36428. [CrossRef]

134. Lambert, S.M.; Langley, D.R.; Garnett, J.A.; Angell, R.; Hedgethorne, K.; Meanwell, N.A.; Matthews, S.J. The crystal structure of NS5A domain 1 from genotype 1a reveals new clues to the mechanism of action for dimeric HCV inhibitors. Protein Sci. 2014, 23, 723-734. [CrossRef]

135. Yin, C.; Goonawardane, N.; Stewart, H.; Harris, M. A role for domain I of the hepatitis C virus NS5A protein in virus assembly. PLoS Pathog. 2018, 14, e1006834. [CrossRef] [PubMed]

136. Lim, Y.S.; Hwang, S.B. Hepatitis C virus NS5A protein interacts with phosphatidylinositol 4-kinase type IIIalpha and regulates viral propagation. J. Biol. Chem. 2011, 286, 11290-11298. [CrossRef]

137. Foster, T.L.; Gallay, P.; Stonehouse, N.J.; Harris, M. Cyclophilin A interacts with domain II of hepatitis C virus NS5A and stimulates RNA binding in an isomerase-dependent manner. J. Virol. 2011, 85, 7460-7464. [CrossRef] [PubMed]

138. Appel, N.; Zayas, M.; Miller, S.; Krijnse-Locker, J.; Schaller, T.; Friebe, P.; Kallis, S.; Engel, U.; Bartenschlager, R. Essential role of domain III of nonstructural protein 5A for hepatitis C virus infectious particle assembly. PLoS Pathog. 2008, 4, e1000035. [CrossRef]

139. Goonawardane, N.; Gebhardt, A.; Bartlett, C.; Pichlmair, A.; Harris, M. Phosphorylation of Serine 225 in Hepatitis C Virus NS5A Regulates Protein-Protein Interactions. J. Virol. 2017, 91, e00805-17. [CrossRef]

140. Goonawardane, N.; Ross-Thriepland, D.; Harris, M. Regulation of hepatitis C virus replication via threonine phosphorylation of the NS5A protein. J. Gen. Virol. 2018, 99, 62-72. [CrossRef]

141. Ross-Thriepland, D.; Mankouri, J.; Harris, M. Serine phosphorylation of the hepatitis C virus NS5A protein controls the establishment of replication complexes. J. Virol. 2015, 89, 3123-3135. [CrossRef] [PubMed]

142. Eyre, N.S.; Hampton-Smith, R.J.; Aloia, A.L.; Eddes, J.S.; Simpson, K.J.; Hoffmann, P.; Beard, M.R. Phosphorylation of NS5A Serine-235 is essential to hepatitis C virus RNA replication and normal replication compartment formation. Virology 2016, 491, 27-44. [CrossRef] [PubMed] 
143. Chong, W.M.; Hsu, S.C.; Kao, W.T.; Lo, C.W.; Lee, K.Y.; Shao, J.S.; Chen, Y.H.; Chang, J.; Chen, S.S.; Yu, M.J. Phosphoproteomics Identified an NS5A Phosphorylation Site Involved in Hepatitis C Virus Replication. J. Biol. Chem. 2016, 291, 3918-3931. [CrossRef]

144. Klinker, S.; Stindt, S.; Gremer, L.; Bode, J.G.; Gertzen, C.G.W.; Gohlke, H.; Weiergraber, O.H.; Hoffmann, S.; Willbold, D. Phosphorylated tyrosine 93 of hepatitis $C$ virus nonstructural protein 5A is essential for interaction with host c-Src and efficient viral replication. J. Biol. Chem. 2019, 294, 7388-7402. [CrossRef]

145. Appel, N.; Pietschmann, T.; Bartenschlager, R. Mutational analysis of hepatitis C virus nonstructural protein 5A: Potential role of differential phosphorylation in RNA replication and identification of a genetically flexible domain. J. Virol. 2005, 79, 3187-3194. [CrossRef] [PubMed]

146. Quintavalle, M.; Sambucini, S.; Di Pietro, C.; De Francesco, R.; Neddermann, P. The alpha isoform of protein kinase CKI is responsible for hepatitis C virus NS5A hyperphosphorylation. J. Virol. 2006, 80, 11305-11312. [CrossRef] [PubMed]

147. Quintavalle, M.; Sambucini, S.; Summa, V.; Orsatti, L.; Talamo, F.; De Francesco, R.; Neddermann, P. Hepatitis C virus NS5A is a direct substrate of casein kinase I-alpha, a cellular kinase identified by inhibitor affinity chromatography using specific NS5A hyperphosphorylation inhibitors. J. Biol. Chem. 2007, 282, 5536-5544. [CrossRef] [PubMed]

148. Masaki, T.; Matsunaga, S.; Takahashi, H.; Nakashima, K.; Kimura, Y.; Ito, M.; Matsuda, M.; Murayama, A.; Kato, T.; Hirano, $\mathrm{H}$; ; et al. Involvement of hepatitis C virus NS5A hyperphosphorylation mediated by casein kinase I-alpha in infectious virus production. J. Virol. 2014, 88, 7541-7555. [CrossRef] [PubMed]

149. Harak, C.; Meyrath, M.; Romero-Brey, I.; Schenk, C.; Gondeau, C.; Schult, P.; Esser-Nobis, K.; Saeed, M.; Neddermann, P.; Schnitzler, P.; et al. Tuning a cellular lipid kinase activity adapts hepatitis $\mathrm{C}$ virus to replication in cell culture. Nat. Microbiol. 2016, 2, 16247. [CrossRef]

150. Goonawardane, N.; Yin, C.; Harris, M. Phenotypic analysis of mutations at residue 146 provides insights into the relationship between NS5A hyperphosphorylation and hepatitis C virus genome replication. J. Gen. Virol. 2020, 101, 252-264. [CrossRef] [PubMed]

151. Sarnow, P.; Sagan, S.M. Unraveling the Mysterious Interactions Between Hepatitis C Virus RNA and Liver-Specific MicroRNA-122. Annu. Rev. Virol. 2016, 3, 309-332. [CrossRef] [PubMed]

152. Wang, H.; Perry, J.W.; Lauring, A.S.; Neddermann, P.; De Francesco, R.; Tai, A.W. Oxysterol-binding protein is a phosphatidylinositol 4-kinase effector required for HCV replication membrane integrity and cholesterol trafficking. Gastroenterology 2014, 146, 1373-1385.e11. [CrossRef] [PubMed]

153. Hofmann, S.; Krajewski, M.; Scherer, C.; Scholz, V.; Mordhorst, V.; Truschow, P.; Schobel, A.; Reimer, R.; Schwudke, D.; Herker, E. Complex lipid metabolic remodeling is required for efficient hepatitis C virus replication. Biochim. Biophys. Acta Mol. Cell Biol. Lipids 2018, 1863, 1041-1056. [CrossRef] [PubMed]

154. Weng, L.; Hirata, Y.; Arai, M.; Kohara, M.; Wakita, T.; Watashi, K.; Shimotohno, K.; He, Y.; Zhong, J.; Toyoda, T. Sphingomyelin activates hepatitis C virus RNA polymerase in a genotype-specific manner. J. Virol. 2010, 84, 11761-11770. [CrossRef] [PubMed]

155. Hirata, Y.; Ikeda, K.; Sudoh, M.; Tokunaga, Y.; Suzuki, A.; Weng, L.; Ohta, M.; Tobita, Y.; Okano, K.; Ozeki, K.; et al. Selfenhancement of hepatitis C virus replication by promotion of specific sphingolipid biosynthesis. PLoS Pathog. 2012, 8, e1002860. [CrossRef]

156. Gewaid, H.; Aoyagi, H.; Arita, M.; Watashi, K.; Suzuki, R.; Sakai, S.; Kumagai, K.; Yamaji, T.; Fukasawa, M.; Kato, F.; et al. Sphingomyelin Is Essential for the Structure and Function of the Double-Membrane Vesicles in Hepatitis C Virus RNA Replication Factories. J. Virol. 2020, 94, e01080-20. [CrossRef]

157. Li, Q.; Pene, V.; Krishnamurthy, S.; Cha, H.; Liang, T.J. Hepatitis C virus infection activates an innate pathway involving IKK-alpha in lipogenesis and viral assembly. Nat. Med. 2013, 19, 722-729. [CrossRef]

158. Machlin, E.S.; Sarnow, P.; Sagan, S.M. Masking the $5^{\prime}$ terminal nucleotides of the hepatitis $C$ virus genome by an unconventional microRNA-target RNA complex. Proc. Natl. Acad. Sci. USA 2011, 108, 3193-3198. [CrossRef] [PubMed]

159. Mortimer, S.A.; Doudna, J.A. Unconventional miR-122 binding stabilizes the HCV genome by forming a trimolecular RNA structure. Nucleic Acids Res. 2013, 41, 4230-4240. [CrossRef] [PubMed]

160. Henke, J.I.; Goergen, D.; Zheng, J.; Song, Y.; Schuttler, C.G.; Fehr, C.; Junemann, C.; Niepmann, M. microRNA-122 stimulates translation of hepatitis C virus RNA. EMBO J. 2008, 27, 3300-3310. [CrossRef]

161. Kunden, R.D.; Khan, J.Q.; Ghezelbash, S.; Wilson, J.A. The Role of the Liver-Specific microRNA, miRNA-122 in the HCV Replication Cycle. Int. J. Mol. Sci. 2020, 21, 5677. [CrossRef]

162. Kincaid, R.P.; Lam, V.L.; Chirayil, R.P.; Randall, G.; Sullivan, C.S. RNA triphosphatase DUSP11 enables exonuclease XRN-mediated restriction of hepatitis C virus. Proc. Natl. Acad. Sci. USA 2018, 115, 8197-8202. [CrossRef] [PubMed]

163. Li, Y.; Masaki, T.; Yamane, D.; McGivern, D.R.; Lemon, S.M. Competing and noncompeting activities of miR-122 and the $5^{\prime}$ exonuclease Xrn1 in regulation of hepatitis C virus replication. Proc. Natl. Acad. Sci. USA 2013, 110, 1881-1886. [CrossRef]

164. Li, Y.; Yamane, D.; Lemon, S.M. Dissecting the roles of the $5^{\prime}$ exoribonucleases Xrn1 and Xrn2 in restricting hepatitis C virus replication. J. Virol. 2015, 89, 4857-4865. [CrossRef]

165. Sedano, C.D.; Sarnow, P. Hepatitis C virus subverts liver-specific miR-122 to protect the viral genome from exoribonuclease Xrn2. Cell Host Microbe 2014, 16, 257-264. [CrossRef] [PubMed]

166. Kumar, A.; Ray, U.; Das, S. Human La protein interaction with GCAC near the initiator AUG enhances hepatitis C Virus RNA replication by promoting linkage between $5^{\prime}$ and $3^{\prime}$ untranslated regions. J. Virol. 2013, 87, 6713-6726. [CrossRef] 
167. Li, Y.; Masaki, T.; Shimakami, T.; Lemon, S.M. hnRNP L and NF90 interact with hepatitis C virus $5^{\prime}$-terminal untranslated RNA and promote efficient replication. J. Virol. 2014, 88, 7199-7209. [CrossRef]

168. Isken, O.; Baroth, M.; Grassmann, C.W.; Weinlich, S.; Ostareck, D.H.; Ostareck-Lederer, A.; Behrens, S.E. Nuclear factors are involved in hepatitis C virus RNA replication. RNA 2007, 13, 1675-1692. [CrossRef] [PubMed]

169. Tsuchihara, K.; Tanaka, T.; Hijikata, M.; Kuge, S.; Toyoda, H.; Nomoto, A.; Yamamoto, N.; Shimotohno, K. Specific interaction of polypyrimidine tract-binding protein with the extreme $3^{\prime}$-terminal structure of the hepatitis $C$ virus genome, the $3^{\prime} X$. J. Virol. 1997, 71, 6720-6726. [CrossRef]

170. Cao, H.; Zhao, K.; Yao, Y.; Guo, J.; Gao, X.; Yang, Q.; Guo, M.; Zhu, W.; Wang, Y.; Wu, C.; et al. RNA binding protein 24 regulates the translation and replication of hepatitis $C$ virus. Protein Cell 2018, 9, 930-944. [CrossRef] [PubMed]

171. Yu, R.; Yang, D.; Lei, S.; Wang, X.; Meng, X.; Xue, B.; Zhu, H. HMGB1 Promotes Hepatitis C Virus Replication by Interaction with Stem-Loop 4 in the Viral 5' Untranslated Region. J. Virol. 2015, 90, 2332-2344. [CrossRef] [PubMed]

172. Qin, Y.; Xun, Z.; Guo, Y.; Chen, S.; Zhu, H. Sam68 Promotes Hepatitis C Virus Replication by Interaction with Stem-Loop 2 of Viral 5' Untranslated Region. J. Virol. 2019, 93, e00693-19. [CrossRef] [PubMed]

173. Wang, Y.; Lee, S.; Ha, Y.; Lam, W.; Chen, S.R.; Dutschman, G.E.; Gullen, E.A.; Grill, S.P.; Cheng, Y.; Furstner, A.; et al. Tylophorine Analogs Allosterically Regulates Heat Shock Cognate Protein 70 And Inhibits Hepatitis C Virus Replication. Sci. Rep. 2017, 7, 10037. [CrossRef] [PubMed]

174. Inoue, Y.; Aizaki, H.; Hara, H.; Matsuda, M.; Ando, T.; Shimoji, T.; Murakami, K.; Masaki, T.; Shoji, I.; Homma, S.; et al. Chaperonin TRiC/CCT participates in replication of hepatitis C virus genome via interaction with the viral NS5B protein. Virology 2011, 410, 38-47. [CrossRef]

175. Kitab, B.; Satoh, M.; Ohmori, Y.; Munakata, T.; Sudoh, M.; Kohara, M.; Tsukiyama-Kohara, K. Ribonucleotide reductase M2 promotes RNA replication of hepatitis C virus by protecting NS5B protein from hPLIC1-dependent proteasomal degradation. $J$. Biol. Chem. 2019, 294, 5759-5773. [CrossRef] [PubMed]

176. Shwetha, S.; Kumar, A.; Mullick, R.; Vasudevan, D.; Mukherjee, N.; Das, S. HuR Displaces Polypyrimidine Tract Binding Protein to Facilitate La Binding to the 3' Untranslated Region and Enhances Hepatitis C Virus Replication. J. Virol. 2015, 89, 11356-11371. [CrossRef] [PubMed]

177. Gupta, G.; Song, J. C-Terminal Auto-Regulatory Motif of Hepatitis C Virus NS5B Interacts with Human VAPB-MSP to Form a Dynamic Replication Complex. PLoS ONE 2016, 11, e0147278. [CrossRef] [PubMed]

178. Zhu, S.L.; Wang, L.; Cao, Z.Y.; Wang, J.; Jing, M.Z.; Xia, Z.C.; Ao, F.; Ye, L.B.; Liu, S.; Zhu, Y. Inducible CYP4F12 enhances Hepatitis C virus infection via association with viral nonstructural protein 5B. Biochem. Biophys. Res. Commun. 2016, 471, 95-102. [CrossRef] [PubMed]

179. Huang, J.T.; Tseng, C.P.; Liao, M.H.; Lu, S.C.; Yeh, W.Z.; Sakamoto, N.; Chen, C.M.; Cheng, J.C. Hepatitis C virus replication is modulated by the interaction of nonstructural protein NS5B and fatty acid synthase. J. Virol. 2013, 87, 4994-5004. [CrossRef] [PubMed]

180. Wang, W.T.; Tsai, T.Y.; Chao, C.H.; Lai, B.Y.; Wu Lee, Y.H. Y-Box Binding Protein 1 Stabilizes Hepatitis C Virus NS5A via Phosphorylation-Mediated Interaction with NS5A To Regulate Viral Propagation. J. Virol. 2015, 89, 11584-11602. [CrossRef]

181. Kasai, H.; Kawakami, K.; Yokoe, H.; Yoshimura, K.; Matsuda, M.; Yasumoto, J.; Maekawa, S.; Yamashita, A.; Tanaka, T.; Ikeda, M.; et al. Involvement of FKBP6 in hepatitis C virus replication. Sci. Rep. 2015, 5, 16699. [CrossRef]

182. Wong, M.T.; Chen, S.S. Human Choline Kinase-alpha Promotes Hepatitis C Virus RNA Replication through Modulation of Membranous Viral Replication Complex Formation. J. Virol. 2016, 90, 9075-9095. [CrossRef]

183. Wong, M.T.; Chen, S.S. Hepatitis C Virus Subverts Human Choline Kinase-alpha To Bridge Phosphatidylinositol-4-Kinase IIIalpha (PI4KIIIalpha) and NS5A and Upregulates PI4KIIIalpha Activation, Thereby Promoting the Translocation of the Ternary Complex to the Endoplasmic Reticulum for Viral Replication. J. Virol. 2017, 91, e00355-17.

184. Liu, Z.; Yang, F.; Robotham, J.M.; Tang, H. Critical role of cyclophilin A and its prolyl-peptidyl isomerase activity in the structure and function of the hepatitis C virus replication complex. J. Virol. 2009, 83, 6554-6565. [CrossRef]

185. Son, K.; Nguyen, T.T.T.; Choi, J.W.; Pham, L.V.; Luong, T.T.D.; Lim, Y.S.; Hwang, S.B. Rad51 Interacts with Non-structural 3 Protein of Hepatitis C Virus and Regulates Viral Production. Front. Microbiol. 2017, 8, 1249. [CrossRef] [PubMed]

186. Lebsir, N.; Goueslain, L.; Farhat, R.; Callens, N.; Dubuisson, J.; Jackson, C.L.; Rouille, Y. Functional and Physical Interaction between the Arf Activator GBF1 and Hepatitis C Virus NS3 Protein. J. Virol. 2019, 93, e01459-18. [CrossRef] [PubMed]

187. Manna, D.; Aligo, J.; Xu, C.; Park, W.S.; Koc, H.; Heo, W.D.; Konan, K.V. Endocytic Rab proteins are required for hepatitis C virus replication complex formation. Virology 2010, 398, 21-37. [CrossRef]

188. Yi, Z.; Fang, C.; Zou, J.; Xu, J.; Song, W.; Du, X.; Pan, T.; Lu, H.; Yuan, Z. Affinity Purification of the Hepatitis C Virus Replicase Identifies Valosin-Containing Protein, a Member of the ATPases Associated with Diverse Cellular Activities Family, as an Active Virus Replication Modulator. J. Virol. 2016, 90, 9953-9966. [CrossRef]

189. Evans, M.J.; Rice, C.M.; Goff, S.P. Phosphorylation of hepatitis C virus nonstructural protein 5A modulates its protein interactions and viral RNA replication. Proc. Natl. Acad. Sci. USA 2004, 101, 13038-13043. [CrossRef] [PubMed]

190. Tu, H.; Gao, L.; Shi, S.T.; Taylor, D.R.; Yang, T.; Mircheff, A.K.; Wen, Y.; Gorbalenya, A.E.; Hwang, S.B.; Lai, M.M. Hepatitis C virus RNA polymerase and NS5A complex with a SNARE-like protein. Virology 1999, 263, 30-41. [CrossRef]

191. Schneider, W.M.; Chevillotte, M.D.; Rice, C.M. Interferon-stimulated genes: A complex web of host defenses. Annu. Rev. Immunol. 2014, 32, 513-545. [CrossRef] [PubMed] 
192. Guo, J.T.; Sohn, J.A.; Zhu, Q.; Seeger, C. Mechanism of the interferon alpha response against hepatitis C virus replicons. Virology 2004, 325, 71-81. [CrossRef] [PubMed]

193. Paeshuyse, J.; Dallmeier, K.; Neyts, J. Ribavirin for the treatment of chronic hepatitis C virus infection: A review of the proposed mechanisms of action. Curr. Opin. Virol. 2011, 1, 590-598. [CrossRef] [PubMed]

194. Zajac, M.; Muszalska, I.; Sobczak, A.; Dadej, A.; Tomczak, S.; Jelinska, A. Hepatitis C-New drugs and treatment prospects. Eur. J. Med. Chem. 2019, 165, 225-249. [CrossRef]

195. McCauley, J.A.; Rudd, M.T. Hepatitis C virus NS3/4a protease inhibitors. Curr. Opin. Pharmacol. 2016, 30, 84-92. [CrossRef]

196. Gao, M.; O'Boyle, D.R., 2nd; Roberts, S. HCV NS5A replication complex inhibitors. Curr. Opin. Pharmacol. 2016, 30, 151-157. [CrossRef]

197. Gao, M.; Nettles, R.E.; Belema, M.; Snyder, L.B.; Nguyen, V.N.; Fridell, R.A.; Serrano-Wu, M.H.; Langley, D.R.; Sun, J.H.; O'Boyle, D.R., 2nd; et al. Chemical genetics strategy identifies an HCV NS5A inhibitor with a potent clinical effect. Nature 2010, 465, 96-100. [CrossRef] [PubMed]

198. Ascher, D.B.; Wielens, J.; Nero, T.L.; Doughty, L.; Morton, C.J.; Parker, M.W. Potent hepatitis C inhibitors bind directly to NS5A and reduce its affinity for RNA. Sci. Rep. 2014, 4, 4765. [CrossRef]

199. Kwon, H.J.; Xing, W.; Chan, K.; Niedziela-Majka, A.; Brendza, K.M.; Kirschberg, T.; Kato, D.; Link, J.O.; Cheng, G.; Liu, X.; et al. Direct binding of ledipasvir to HCV NS5A: Mechanism of resistance to an HCV antiviral agent. PLoS ONE 2015, 10, e0122844. [CrossRef] [PubMed]

200. Eltahla, A.A.; Luciani, F.; White, P.A.; Lloyd, A.R.; Bull, R.A. Inhibitors of the Hepatitis C Virus Polymerase; Mode of Action and Resistance. Viruses 2015, 7, 5206-5224. [CrossRef]

201. Villalba, B.; Li, J.; Johnson, K.A. Resistance to excision determines efficiency of hepatitis C virus RNA-dependent RNA polymerase inhibition by nucleotide analogs. J. Biol. Chem. 2020, 295, 10112-10124. [CrossRef]

202. Boehr, A.K.; Arnold, J.J.; Oh, H.S.; Cameron, C.E.; Boehr, D.D. 2'-C-methylated nucleotides terminate virus RNA synthesis by preventing active site closure of the viral RNA-dependent RNA polymerase. J. Biol. Chem. 2019, 294, 16897-16907. [CrossRef] [PubMed]

203. Soriano, V.; Vispo, E.; de Mendoza, C.; Labarga, P.; Fernandez-Montero, J.V.; Poveda, E.; Trevino, A.; Barreiro, P. Hepatitis C therapy with HCV NS5B polymerase inhibitors. Expert Opin. Pharmacother. 2013, 14, 1161-1170. [CrossRef]

204. Li, D.K.; Chung, R.T. Overview of Direct-Acting Antiviral Drugs and Drug Resistance of Hepatitis C Virus. Methods Mol. Biol. 2019, 1911, 3-32. [PubMed]

205. Deredge, D.; Li, J.; Johnson, K.A.; Wintrode, P.L. Hydrogen/Deuterium Exchange Kinetics Demonstrate Long Range Allosteric Effects of Thumb Site 2 Inhibitors of Hepatitis C Viral RNA-dependent RNA Polymerase. J. Biol. Chem. 2016, 291, 10078-10088. [CrossRef]

206. Li, J.; Johnson, K.A. Thumb Site 2 Inhibitors of Hepatitis C Viral RNA-dependent RNA Polymerase Allosterically Block the Transition from Initiation to Elongation. J. Biol. Chem. 2016, 291, 10067-10077. [CrossRef]

207. European Association for Study of Liver. EASL Clinical Practice Guidelines: Management of hepatitis C virus infection. J. Hepatol. 2014, 60, 392-420. [CrossRef]

208. Pawlotsky, J.M. Hepatitis C Virus Resistance to Direct-Acting Antiviral Drugs in Interferon-Free Regimens. Gastroenterology 2016, 151, 70-86. [CrossRef] [PubMed]

209. Neumann, A.U.; Lam, N.P.; Dahari, H.; Gretch, D.R.; Wiley, T.E.; Layden, T.J.; Perelson, A.S. Hepatitis C viral dynamics in vivo and the antiviral efficacy of interferon-alpha therapy. Science 1998, 282, 103-107. [CrossRef] [PubMed]

210. Halfon, P.; Locarnini, S. Hepatitis C virus resistance to protease inhibitors. J. Hepatol. 2011, 55, 192-206. [CrossRef] [PubMed]

211. Sarrazin, C. The importance of resistance to direct antiviral drugs in HCV infection in clinical practice. J. Hepatol. 2016, 64, 486-504. [CrossRef]

212. Lenz, O.; Verbinnen, T.; Fevery, B.; Tambuyzer, L.; Vijgen, L.; Peeters, M.; Buelens, A.; Ceulemans, H.; Beumont, M.; Picchio, G.; et al. Virology analyses of HCV isolates from genotype 1-infected patients treated with simeprevir plus peginterferon/ribavirin in Phase IIb/III studies. J. Hepatol. 2015, 62, 1008-1014. [CrossRef]

213. Pham, L.V.; Jensen, S.B.; Fahnoe, U.; Pedersen, M.S.; Tang, Q.; Ghanem, L.; Ramirez, S.; Humes, D.; Serre, S.B.N.; Schonning, K.; et al. HCV genotype 1-6 NS3 residue 80 substitutions impact protease inhibitor activity and promote viral escape. J. Hepatol. 2019, 70, 388-397. [CrossRef]

214. Nejabat, N.; Hosseini, S.Y.; Sarvari, J.; Gorzin, A.A.; Fattahi, M.R.; Rasoolian, M. The Investigation of Drug Resistance Substitutions in NS3 Protease Sequence of Hepatitis C Virus from Non-Responder Patients. Asian Pac. J. Cancer Prev. 2019, 20, $2311-2317$. [CrossRef]

215. Kai, Y.; Hikita, H.; Morishita, N.; Murai, K.; Nakabori, T.; Iio, S.; Hagiwara, H.; Imai, Y.; Tamura, S.; Tsutsui, S.; et al. Baseline quasispecies selection and novel mutations contribute to emerging resistance-associated substitutions in hepatitis $\mathrm{C}$ virus after direct-acting antiviral treatment. Sci. Rep. 2017, 7, 41660. [CrossRef]

216. Simicic, P.; Grgic, I.; Santak, M.; Vince, A.; Lepej, S.Z. Frequency of baseline NS5A resistance-associated substitutions in patients infected with genotype 1 of hepatitis C virus in Croatia. Microb. Pathog. 2019, 136, 103694. [CrossRef] [PubMed]

217. Caudai, C.; Materazzi, A.; Saladini, F.; Di Giambenedetto, S.; Torti, C.; Ricciardi, B.; Rossetti, B.; Almi, P.; De Luca, A.; Zazzi, M Natural NS5A inhibitor resistance associated substitutions in hepatitis C virus genotype 1 infected patients from Italy. Clin. Microbiol. Infect. 2018, 24, 308.e5-308.e8. 
218. Nakamoto, S.; Kanda, T.; Wu, S.; Shirasawa, H.; Yokosuka, O. Hepatitis C virus NS5A inhibitors and drug resistance mutations. World J. Gastroenterol. 2014, 20, 2902-2912. [CrossRef] [PubMed]

219. Nettles, J.H.; Stanton, R.A.; Broyde, J.; Amblard, F.; Zhang, H.; Zhou, L.; Shi, J.; McBrayer, T.R.; Whitaker, T.; Coats, S.J.; et al. Asymmetric binding to NS5A by daclatasvir (BMS-790052) and analogs suggests two novel modes of HCV inhibition. J. Med. Chem. 2014, 57, 10031-10043. [CrossRef]

220. Kati, W.; Koev, G.; Irvin, M.; Beyer, J.; Liu, Y.; Krishnan, P.; Reisch, T.; Mondal, R.; Wagner, R.; Molla, A.; et al. In vitro activity and resistance profile of dasabuvir, a nonnucleoside hepatitis $C$ virus polymerase inhibitor. Antimicrob. Agents Chemother. 2015, 59, 1505-1511. [CrossRef]

221. Lindenbach, B.D.; Evans, M.J.; Syder, A.J.; Wolk, B.; Tellinghuisen, T.L.; Liu, C.C.; Maruyama, T.; Hynes, R.O.; Burton, D.R.; McKeating, J.A.; et al. Complete replication of hepatitis C virus in cell culture. Science 2005, 309, 623-626. [CrossRef]

222. Neufeldt, C.J.; Cortese, M.; Acosta, E.G.; Bartenschlager, R. Rewiring cellular networks by members of the Flaviviridae family. Nat. Rev. Microbiol. 2018, 16, 125-142. [CrossRef] 